Cite as: Alessia Napoleone, Alessandro Pozzetti, Marco Macchi. A framework to manage reconfigurability in manufacturing. International Journal of Production Research, vol. 56, issue $11,3815-3837,2018$

POST-PRINT Version

\title{
A Framework to Manage Reconfigurability in Manufacturing
}

\author{
Alessia Napoleone ${ }^{\mathrm{a} *}$, Alessandro Pozzetti ${ }^{\mathrm{a}}$ and Marco Macchi ${ }^{\mathrm{a}}$ \\ ${ }^{a}$ Department of Management, Economics and Industrial Engineering, Politecnico di \\ Milano, Milano, Italy \\ *+39 3331306 533, +390223994763, alessia.napoleone@ polimi.it; \\ +390223994752 alessandro.pozzetti@ polimi.it; \\ +390223992726 marco.macchi@polimi.it
}




\section{A Framework to Manage Reconfigurability in Manufacturing}

Nowadays, manufacturing firms are dealing with the unpredictability of market requirements and the frequent changes induced by technological innovation. For this reason, firms are more and more addressing the need to be responsive at an affordable cost. To do so, they are required to develop a capability called reconfigurability. This paper is a review of the existing literature because the current need makes interesting to reflect on the state of the art of reconfigurability as a concept. This reflection has led to focus on reconfigurability characteristics for both their relevance and their relationships with managerial decisions in manufacturing. To this end, a framework has been proposed. It is based on system lifecycle and production levels. These two elements have been deduced from literature and identified as relevant dimensions for decision making.

Keywords: reconfigurability characteristics, relationships between reconfigurability characteristics, reconfigurability across production levels, framework of reconfigurability, reconfigurability capability

\section{Introduction}

Manufacturing firms are facing the challenge of surviving in the current context characterized by unpredictable and frequent market changes and the demand for products with shortened life cycles (Koren, Wang and $\mathrm{Gu}$, 2016). The fact that market is increasingly demanding products variations has led to the concept of evolvable product families (ElMaraghy, 2007). In other words, the products variations are increasing in scope and frequency. In order to manufacture new/changed product families, firms need to change one or more processes and rearrange resources. In this scenario, manufacturing firms need to develop the reconfigurability capability (Shaik, Rao and Rao, 2014). Reconfigurability is the ability to repeatedly change and/or rearrange the components of a system in a cost-effective way, to meet new environmental and technological changes (Setchi and Lagos, 2004; Abdi, 2009). Recently, reconfigurability is also perceived as a relevant paradigm in order to meet current impelling needs in terms of economic, 
environmental and social sustainability. For example, according to Dubey et al. (2017), manufacturing systems with higher reconfigurability provide better environmental performance (Garbie, 2014; Dubey, Gunasekaran and Chakrabarty, 2015; Dubey et al., 2017).

Reconfigurability is a capability that has been widely studied in the literature referred to Reconfigurable Manufacturing Systems (RMSs). RMSs are 'systems designed at the outset for rapid change, in order to quickly adjust production capacity and functionality within a part family' (Koren, 2006). Over time, these systems allow evolving/customized flexibility (Wiendahl et al., 2007). In fact, since they are adaptable to evolving requirements, they provide the required functionality and the capacity exactly when needed (ElMaraghy, 2006). RMSs have been described as machining systems provided with modular structure, both hardware and software. Their reconfiguration allows to add, remove, or modify specific process capabilities, controls, software, or machine structure to adjust production capacity in response to changing market demand or technologies (Mehrabi, Ulsoy and Koren, 2000b; Niroomand, Kuzgunkaya and Bulgak, 2014). Despite the generalizability of RMSs' definition, many authors, when referring to RMSs, limited their focus on specific systems. Indeed, RMSs' components are Computerized Numerically Controlled (CNC) machines, Reconfigurable Machines (RMs), Reconfigurable Machine Tools (RMTs), inspection machines, material-handling devices and systems (ElMaraghy, 2006; Bi et al., 2008b; Essafi, Delorme and Dolgui, 2012; Haddou Benderbal, Dahane and Benyoucef, 2017; Prasad and Jayswal, 2017; Borisovsky, Delorme and Dolgui, 2014; Vafadar, Hayward and Tolouei-Rad, 2017).

Today reconfigurability is needed in a broader field of applications; even industries that traditionally compete in stable contexts are requiring reconfigurability. For example, the process industry, normally focused on process productivity, is facing the 
need to be market driven (Crama, Pochet and Wera, 2001; Shah, 2005). This need is leading to changes to the processes themselves. From another perspective, regarding manufacturing systems, Rehman and Subash Babu (2013) conducted an interesting search aimed at associating reconfigurability also to not technology-based practices.

For the aforementioned reason, the present paper is an investigation on the concept of reconfigurability as a capability and not on issues related specifically to RMSs. Indeed, this capability is influent for decisions related to both the design as well as the operations of manufacturing systems (Koren, 2010). Thus, studying reconfigurability in a general way allows revealing common decision making structures to use reconfigurability as enabler of responsiveness of manufacturing firms.

Therefore, the available literature has been explored to address the following two sets of research questions. Specifically, answering to the first set of research questions (RQs1) can be seen as the intermediate objective to prepare the ground for the second set of research questions (RQs2).

- RQs1. According to literature, what are the characteristics of reconfigurability (RQ1.1)? Why are they relevant (RQ1.2)?

- RQs2. When do the characteristics act (RQ2.1)? How are they exploited (RQ2.2)? Where can they be located (RQ2.3)?

To this end, the paper is structured in a way that progressively classifies literature according to different concepts. Section 2 uses literature to justify the focus on six core reconfigurability characteristics and to highlight their relevance in terms of positive impacts on reconfiguration effort. Thus, section 2 answers to RQs1. Section 3 exploits literature to: (i) discern that the six characteristics may act in different periods of system lifecycle, (ii) describe a way to exploit characteristics to allow system reconfigurability and (iii) relate characteristics to production levels. Thus, section 3 answers to RQs2, by 
building a general framework to manage reconfigurability in manufacturing. Section 4 concludes, synthesizing the main results of this paper and introducing to future developments.

\section{The core characteristics of reconfigurability and their relevance}

In this section, based on a wide literature review, answers were progressively given to the set of RQs1. Each of the following subsections refers to the specific RQ of interest.

\subsection{According to literature, what are the characteristics of reconfigurability?}

Literature was reviewed and classified in order to identify the core characteristics of reconfigurability. Thus, a table (Table 1) was built, reporting characteristics that authors referred to.

(table 1 here)

Within Table 1, for each reference reported in ascending order of date, the referred characteristics are identified. The totality of characteristics reported are: modularity, integrability, diagnosability, scalability, convertibility, customization (sometimes identified as customized flexibility), mobility, universality, compatibility, automatibility, "self-abilities" (such as, self-optimization, self-healing and self-adaption) and flexibility. The great majority of authors referred to: modularity, integrability, diagnosability, scalability, convertibility and customization. Therefore, in this paper they are considered the 6 core characteristics of reconfigurability. These characteristics are prevalently found in the state of the art of RMSs.

In some works, authors provided descriptions of these six characteristics referring to resources within the shop floor, thus exploiting specific terminology (e.g. reference is made to machine tools, tooling, controls, interfaces, etc.). See, for example, Koren (2014) 
or Makinde, Mpofu and Popoola (2014). Others synthesised the core characteristics more generically. These latter descriptions are reported below.

- Modularity means that all system components, both software and hardware, are designed to be modular (Mehrabi, Ulsoy and Koren, 2000b).

- Integrability means that systems and components are designed for both ready integration and future introduction of new technology (Mehrabi, Ulsoy and Koren, 2000b).

- Diagnosability allows (i) quick identification of the sources of quality and reliability problems (Mehrabi, Ulsoy and Koren, 2000b) and (ii) quick correction of operational problems (Koren and Shpitalni, 2010).

- Scalability allows incremental changes of capacity, rapidly and economically (ElMaraghy, 2006).

- Convertibility 'allows quick changeover between existing products and quick system adaptability for future products' (Mehrabi, Ulsoy and Koren, 2000b).

- Customization allows adaptation of system configuration for producing the required product families (Rösiö, 2012; Koren, 2005; Mehrabi, Ulsoy and Koren, 2000b).

\subsection{Why are reconfigurability characteristics relevant?}

In literature, several papers emphasized that the core characteristics reduce the effort required to reconfigure the manufacturing system (e.g. Koren and Shpitalni, 2010) and this justifies the interest in the six characteristics as components of the reconfigurability capability.

The reconfiguration effort is composed of reconfiguration time, reconfiguration cost and ramp-up time. A definition of these aspects is provided below, starting from the words of Zhang et al. (2006). 
- The reconfiguration time is the period of time taken by system reconfiguration (for instance, the time required to redesign the system or to re-arrange an equipment). Hence, reconfiguration time can be seen as an opportunity cost since it affects the service level due to the losses related to the reconfiguration period.

- The reconfiguration cost is the cost to reconfigure (or adjust) the system to satisfy the requirements of the evolving product families. It is represented by the out-of-pocket costs (for example, the expenses incurred to redesign the system or to buy and install new machines).

- The ramp-up time is the period of time taken by a manufacturing system after reconfiguration to reach a normal production state, at required quality and production rate (see also Koren (2013) for a similar definition).

Synthesizing, Table 2 gathers the references on the impacts of the characteristics in terms of reconfiguration effort, i.e. reduction of reconfiguration time, reconfiguration cost and ramp-up time.

(Table 2 here)

According to Table 2, compared to others characteristics, modularity, integrability, convertibility and scalability reduce both reconfiguration time and cost.

Puik et al. (2016) proved that modularity can reduce reconfiguration time and cost: thanks to the presence of known and tested modular parts (of a manufacturing system), the required reconfiguration time and resources are reduced. Indeed, they presupposed the integrability of these modules, in order to really benefit of modularity. Heisel and Meitzner (2006) pointed out that standardized elements (i.e. modularity and integrability) reduce reconfiguration cost. Aboufazeli (2011) related machine tools integrability to reconfiguration time: to him, integrability influences the speed of the 
replacement of the modules in a manufacturing system; he pointed out that the lack of integrability between physical modules negatively impacts on reconfiguration time.

Ayman, Youssef and ElMaraghy (2006) studied the cost and time required to reconfigure the system and their observations suggest that these aspects depend on scalability and convertibility. Niroomand, Kuzgunkaya and Bulgak (2014) evidenced the impact of scalability on the reduction of reconfiguration time by discussing about the impact of the selection of a configuration of a manufacturing system (in order to ensure a certain production capacity) on the reconfiguration time.

In literature, diagnosability is the only characteristic often associated with the reconfiguration ramp-up time (for example, see (Koren, 2013)). For Koren and Shpitalni (2010), as diagnosability allows in-process diagnostics, it determines the advantage of dramatically shortening the ramp-up periods after reconfigurations. This is confirmed by many other authors (see Table 2), who emphasized the impact of diagnosability on rampup time.

According to some authors, customization allows reducing reconfiguration cost (Koren, 2013; Chaube, Benyoucef and Tiwari, 2012). Despite its scarce presence in Table 2, customization is a very important characteristic. Indeed, Shabaka and ElMaraghy (2007) implicitly overlapped the concepts of reconfigurability and customization. Besides, Goyal, Jain and Jain (2013) wrote that reconfigurable systems are built around product families and their configuration evolves in response to changes in the product functionality and capacity. Remarkably and extremely, Rösiö (2012) did not see customization as a reconfigurability characteristic but rather "as a basis for reconfigurability that distinguishes reconfigurability as customized flexibility from general flexibility". Koren (2005) assumed that customization makes a system "reconfigurable" instead of "flexible". Also to Setchi and Lagos (2004) customization is 
the characteristic that really introduces reconfigurability. Indeed, reconfigurability, allowing a disruptive change, is related to a mid-long term goal, in situations of changed product families. Conversely, flexibility is more related to the short-term goals, in situations of unchanged product families. Summarizing, many authors described customization as the characteristic synthesizing reconfigurability (Koren and Ulsoy, 2002; Abdi and Labib, 2003; Abdi and Labib, 2004b; Koren, 2005; ElMaraghy, 2006; Galan et al., 2007; Shabaka and Elmaraghy, 2007; Rösiö, 2012; ElMaraghy, 2009; Goyal et al., 2013; Zhang et al., 2012; Dou, Dai and Meng, 2010).

\subsection{Concluding remarks}

This section answered to RQs1. Six characteristics - modularity, integrability, diagnosability, convertibility, scalability and customization - are relevant. Indeed, a multitude of authors referred to them (Table 1). Moreover, allowing a reduction of reconfiguration effort (Table 2), they bring benefits to manufacturing firms, thus they are significant components of the reconfigurability capability. Customization is additionally relevant because it synthesizes reconfigurability. Thus, as further addressed in the next section, it may play a different role from other characteristics.

\section{Building a framework to manage reconfigurability in manufacturing}

In this section, to build the framework, answers were progressively given to the set of RQs2. Each of the following subsections refers to the specific RQ of interest.

\subsection{When do the six core characteristics act?}

The six core characteristics can be classified according to their positioning within system lifecycle, in which decisions concerning reconfigurability are made. To the intent of this paper, system lifecycle is simplified in the succession of two stages: the configuration and the reconfiguration periods. 
(Table 3 here)

Table 3 exploits references to catalogue modularity, integrability, diagnosability, convertibility and scalability in either configuration or reconfiguration characteristics. In some papers (the first five within Table 3), modularity, integrability and diagnosability are indicated as supporting characteristics, while scalability and convertibility are essential ones (Koren, 2005; Wiendahl et al., 2007; Koren and Shpitalni, 2010; Rösiö, 2012; Hasan, Jain and Kumar, 2014). For some authors (Koren and Shpitalni, 2010; Rösiö, 2012) modularity, integrability and diagnosability do not guarantee modifications in production capacity and functionality, but they have an impact on essential characteristics. Thus, these three characteristics can be associated to the configuration period, i.e. the period for decisions on structural characteristics of systems. Moreover, according to Rösiö (2012), essential characteristics (i.e. scalability and convertibility) lead to capacity or functionality changes of the production system and thus reconfigurability. Therefore, they can be associated to the reconfiguration period, i.e. the period for decisions on system changes.

The first five references of Table 3 constitute the basis for the classification provided within this section. Besides, to further investigate on the configuration and reconfiguration characteristics, other papers focused on the operations of reconfigurable systems were analysed. In fact, even if almost all researchers mentioning the core characteristics presented them as design characteristics, the operations of manufacturing systems comprise issues which are relevant for reconfigurability, such as part families formation, reconfigurability planning, quality management, risk management and exception handling. These issues can be associated to some of the characteristics. For example, to Galan et al. (2007) the working of a reconfigurable system starts with an initial classification in product families, then the system is reconfigured in order to 
provide the functionality (i.e. convertibility) and capacity (i.e. scalability) that allow producing evolving product families. For Heisel and Meitzner (2006) 'the reconfigurability of a system derives from the system's configurability'. To them, the configuration consists in the design, the selection and the composition of modules from a modular construction set (i.e. physical modularity and integrability of modules), according to the specifications and requirements of the user. Reconfigurations are later conversions and modifications of functionality and capacity by replacing, supplementing and removing discrete, autonomously operating components.

For modularity, integrability, scalability and convertibility other papers referring to the operations of manufacturing systems confirmed what already stated by the first five references of the table. However, as noticeable in Table 3, for diagnosability the results were slightly different. Bruccoleri, Pasek and Koren (2006) described exception handling as the policy meant for countering unwanted effects of exceptions (such as machine breakdowns and reworks due to quality problems) and for recovering from errors caused by exception occurrences. Thus, it is inferable that diagnosability should act as a realtime decision support, allowing operational decisions regarding reconfiguration for exception handling. Valente (2016) identified operational advantages of having the design characteristics of modularity and interchangeability (i.e. integrability). More precisely, she mentioned two advantages: (i) versatility, the operational capability of robots to disassemble and reassemble to form new morphologies that are better suited for new tasks (i.e. convertibility) and (ii) robustness, the operational capability of robots to replace faulty parts autonomously, thus leading to self-repair behaviours (i.e. diagnosability). To strengthen the twofold nature of diagnosability, the concept of redundancy can be representative (see the last two references of Table 3). To Freiheit et al. (2004), the configuration of a manufacturing system could imply the presence of 
structural redundancies (e.g. standby machines) allowing isolating failures in the manufacturing system, thus permitting production to continue. To $\mathrm{Gu}$ et al. (2015), systems should be provided with built-in redundancy. Such capability would allow reconfigurable systems being adjustable to intrinsic system events (e.g. machine faults or failures) (Gu et al., 2015). Muller, Grunewald and Spengler (2017) also referred to redundant configurations, in which stations automatically take over the operations of failed stations in the event of failure. Overall, redundancy (associable to diagnosability) plays an important role not only for the configuration of a manufacturing system, but also for its reconfiguration.

Table 3 synthesizes the results of the classification: (i) modularity and integrability can be associated to the configuration period (as they are configuration characteristics); (ii) scalability and convertibility can be associated to the reconfiguration one (as reconfiguration characteristics); and (iii) diagnosability can be associated to both periods. Accordingly, in terms of decision making: (i) modularity and integrability, being related to decisions on system design, are clearly bounded to the configuration period of system lifecycle; (ii) scalability and convertibility, being related to operational decisions, pertain to the reconfiguration period of lifecycle; and (iii) diagnosability is related to both design and operations decisions.

The sixth and last characteristics - i.e. customization - is relevant as it synthesizes reconfigurability (as already discussed in section 2). Indeed, literature insights allow hypothesizing that it could be both "trigger of" and "triggered by" reconfigurability. In particular, customization can be interpreted as a change driven characteristic, i.e. "trigger of" reconfigurability. It allows the system continuously changing according to new requirements; it allows quickly reacting to changes induced to manufacture new product families. Customization can be also interpreted as a change driver characteristic, i.e. 
"triggered by" reconfigurability. Its presence ensures that the system can evolve to meet any physical or managerial change. Therefore, allowing firms to proactively face changes, customization should be exploited as a change driver characteristic, in order to gain competitive advantage through changes. Conversely, firms should avoid to exploit it as a change driven characteristic, thus only reacting to changes due to the context. In terms of decision making, compared to other characteristics, customization has a strategic role. It leads to either a proactive or reactive approach to exploit reconfigurability.

Figure 1 synthesizes the main aspects analysed in this section. To be reconfigurable, a system should be provided with a certain starting level of modularity, integrability and diagnosability, i.e. the configuration characteristics, decided during the configuration period (in terms of lifecycle stage). This starting level affects the ability to modify the configuration, which depends on diagnosability, scalability and convertibility, i.e. the reconfiguration characteristics, exploited during the reconfiguration period (in terms of lifecycle stage). In turn, customization affects/is affected by the required product families because the configuration has to change according to the changed demand.

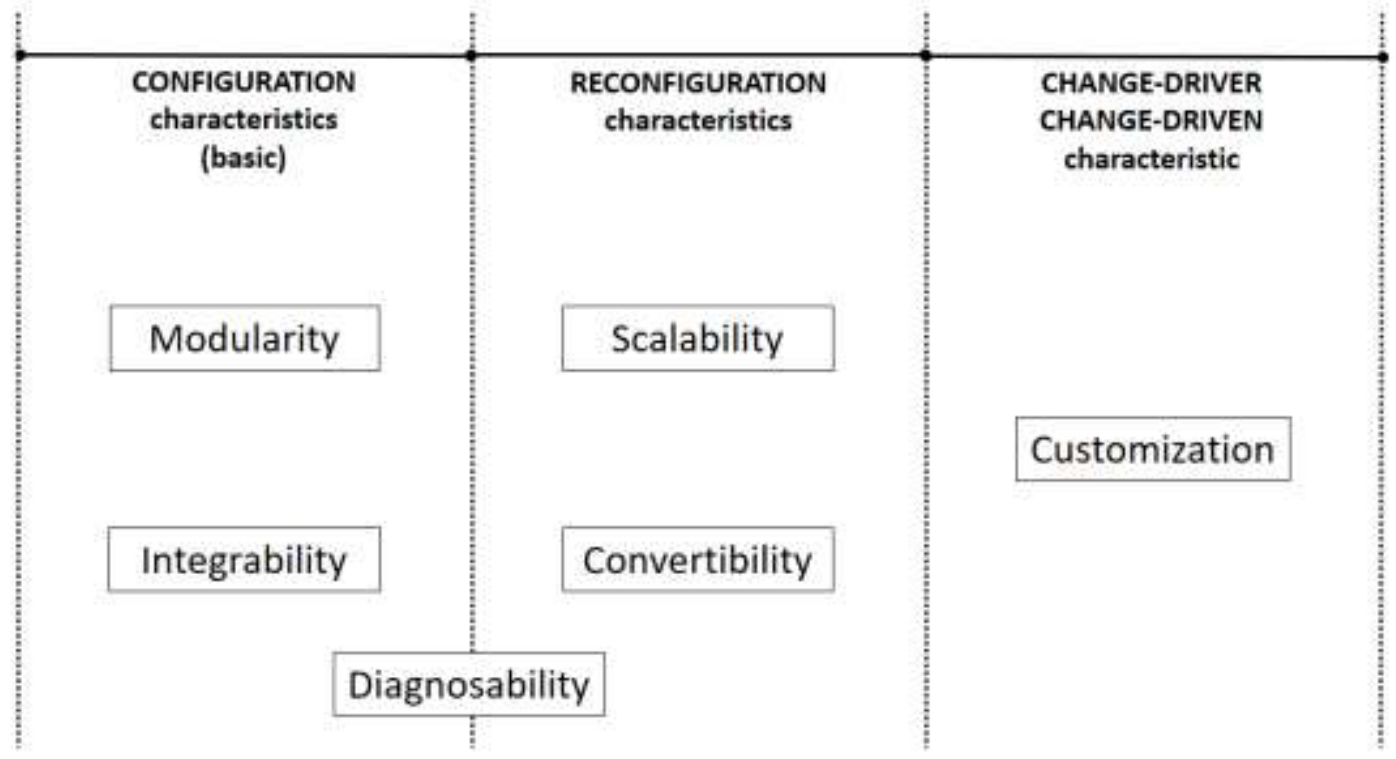

Figure 1 Configuration, reconfiguration and change-driver/driven characteristics in system lifecycle 


\subsection{How are the six core characteristics exploited?}

The six characteristics are related with each other; this fact already arose within section 3.1. Identifying the relationships could ensure the completeness of the framework. Thus, the following table (Table 4) synthesizes the insights, collected from literature, on the relationships between the six characteristics. The rows are the influencing characteristics, the columns are the influenced ones. The matrix is not symmetric, the only bidirectional relationship is the one between modularity and integrability, this is due to the fact that the relationship between these two characteristics is so close that is not easy to distinguish which of the two influences the other.

(Table 4 here)

The close relationship between integrability and modularity is outstanding. According to Mesa et al. (2014), modularity is the most important characteristic due to the possibility of having optimized interfaces and the possibility to change modules. These possibilities are associable to integrability. In general, Shaik, Rao and Rao (2014) referred to interchangeability (then integrability) between process modules. Moreover, they identified the need to standardize the production of modular manufacturing machinery (i.e. modularity requires integrability). For Puik et al. (2016) modular parts are building blocks for manufacturing systems that can be reused; the possibility to reuse such building blocks should imply their integrability. Often authors evidenced this relationship from a technical point of view; they frequently referred to the need to standardize, i.e. to make integrable, the modular (hardware) components (see for instance Bi et al. (2008)).

Fredriksson (2006) brought the concepts of coordination and modularity to highlight that the need to satisfy the evolving demand leads to the need to coordinate modules in order to reach a new configuration. The novelty of his paper lies in the fact 
that he refers to 'organizational modules', therefore, unlike the previous citations, he introduces aspects related to modularity which are not technical. In his reasoning, organizational modules need to be independently managed and are responsible of product modules, bringing the need for coordination. Thus, Fredriksson's reasoning highlights the relationship between modularity, intended as organizational modules, integrability and customization. The necessity of coordination is highlighted also by Zhang et al. (2015), who, more specifically, refer to reconfigurable systems. Indeed, Zhang et al. (2015) confirms that something more than technical aspects is needed, stressing the necessity to communicate and to manage activities.

Regarding modularity, integrability, scalability and convertibility, Heisel and Meitzner (2006) emphasized the dependence of scalability and convertibility on modularity and integrability and the overall relationship of these characteristics with customization. Koren, in his papers, exploited the concept of modularity supporting scalability and convertibility of a system (see, as an example, Koren and Shpitalni, 2010). Some authors clearly evidenced a relationship between modularity and convertibility, in particular modularity simplifies convertibility (Gumasta et al., 2011; Hasan, Jain and Kumar, 2014). Other authors pointed out that modularity influences scalability (Deif and ElMaraghy, 2007a; Wang and Koren, 2012). Puik et al. (2016) clearly showed how part modules are the 'basis' for scalability and convertibility: they explained that reconfigurability implies the presence of modules that could be either repeated, or adapted (than converted), or expanded (then scaled) in order to reconfigure the system.

Regarding scalability, convertibility and customization, Shabaka and ElMaraghy (2007) emphasized the impact of scalability and convertibility on customization. They wrote that customization is realized by adjusting resources, for example (i) by adding/removing machines, changing system layout, then scaling the resources (at system 
level) or (ii) by adding/removing an axis of motion and/or a spindle or integrating new process monitoring technology, then converting the resources (at machine tool level).

The influence of integrability and modularity on diagnosability seems deducible. Some authors focused on the role of emerging technologies (e.g. Cyber Physical Systems -CPSs- and Semantic technologies) to allow reconfigurability. In particular, Garetti, Fumagalli and Negri (2015) discussed that the presence of CPSs enable software and hardware modularity. Moreover, CPSs should exploit semantic technology to be integrable, as already suggested by Lastra and Delamer (2006). The combined presence of integrability and modularity gives enormous benefits in terms of reduction of system reconfiguration time and ramp-up time (Negri et al., 2016; Valente, 2016; Bruccoleri, Amico and Perrone, 2003). Thus, these authors seem to corroborate the hypothesis on the relationship between modularity, integrability and - through the ramp-up time (see what already discussed in section 2) - diagnosability. Moreover, owing to the reduction of reconfiguration ramp-up time, it is possible to infer that diagnosability has an impact on the possibility to use scalability and convertibility as reconfiguration characteristics. More explicitly, Koren (2013) wrote that scalability and diagnosability complement to each other because scaling-up of an existing system to cope with changing demand requires a subsequent ramp-up period that can be reduced dramatically by implementing the diagnosability characteristic. 


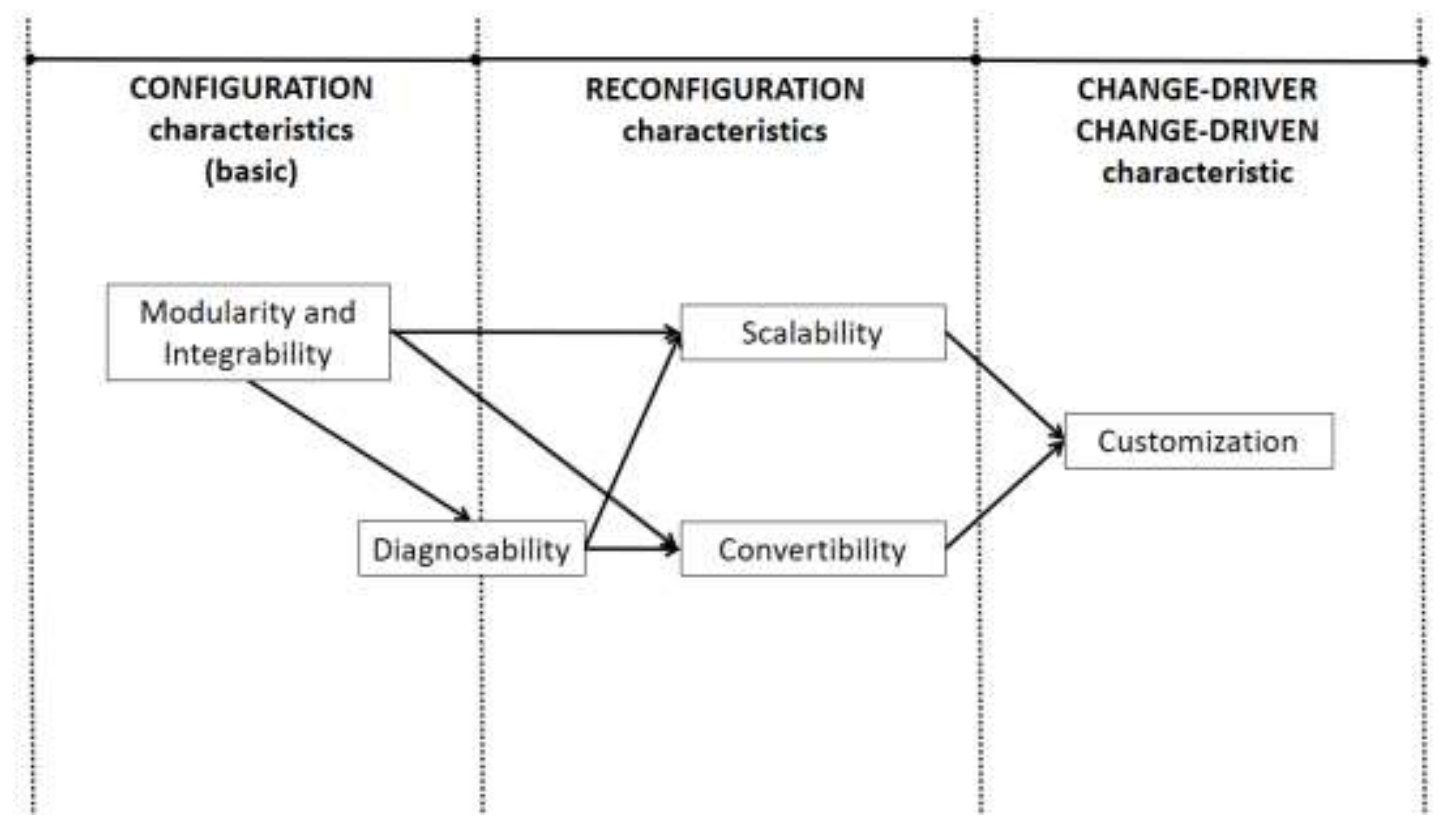

Figure 2 Relationships between reconfigurability characteristics in system lifecycle

Figure 2 gathers the observations of sections 3.1 and 3.2. Indeed, it adds to the classification of characteristics along the dimension of system lifecycle stages (Figure 1), the visual representation of the relationships between characteristics. In terms of decision making, relationships make evident the impacts of decisions on some characteristics on possible decisions on other characteristics: modularity and integrability impact on scalability and convertibility, which, in turn, impact on customization (thus, modularity and integrability indirectly impact on customization); diagnosability is influenced by integrability and modularity and, in turn, it influences scalability and convertibility.

\subsection{Where can the six core characteristics be located?}

Potentially, the six core characteristics could be referred to production levels. In this regard, Andersen, Brunoe and Nielsen (2015) wrote that reconfigurable manufacturing involves the ability to reconfigure at different production levels. Thus, to complete the framework of reconfigurability, production levels should be considered. Andersen, Brunoe and Nielsen (2015), defined six levels: network, factory, segment, system, cell 
and workstation. To them, network is 'the highest structuring level, which comprises the network of sites that the manufacturing company is embedded in'; factory is 'the level of the plant, covering the building and its infrastructure'; segment is 'the level above the system, which contains all activities involved in manufacturing and making ship-ready products'; system is 'the level containing interlinked cells used for manufacturing variants of a part or a product family'; cell is 'the level covering a subsystem of the system, containing groups of work stations and material handling that perform most activities to finish a part'; workstation is 'the lowest structuring level, containing single workstations and machines that add a feature to a work piece'.

A similar classification was earlier proposed by Wiendahl et al. (2007).

For some authors reconfigurability at lower levels is principally obtained through physical/hard activities, while at upper levels it is mainly obtained through soft activities (Bi et al., 2008a; Ayman, Youssef and ElMaraghy, 2006; Andersen, Brunoe and Nielsen, 2015). Overall, authors provided insights on the relationship between reconfigurability and production levels; however, a consolidated and systematic interpretation of the six core characteristics of reconfigurability in accordance with these production levels seems missing.

For the purpose of this paper, it was decided to associate reconfigurability to only four production levels - two of them resulting from the merging of different levels identified by literature -, instead of six. Indeed, in practical cases, it is often not easy to identify clearly this high number of levels because their boundaries are sometimes faded. The descriptions of the four levels are proposed below, basing on the contributions provided by literature. 
- Workstation/Machine level. It is the lowest structuring one, containing single operators and machines that generally perform a technological operation.

- System level. The proposed-by-literature system and cell levels have been merged into this one. The system level herein considered contains interlinked subsystems made of groups of workstations and material handling used for manufacturing variants of a part or a product family. System configurations can be either cells, lines or production departments. Generally, it is possible to distinguish between production and assembly systems, depending on the kind of activities performed.

- Factory/Plant level. The proposed-by-literature factory and segment levels have been merged into this one. The factory level herein considered is a production site made of production and/or assembly systems, which can be described as a node of a production network or a supply chain.

- Network level. It is the highest structuring level, it can be seen as the set of production sites linked by material and information flows along the supply chain.

In the remainder of the paper, network level will not be considered because of the choice of authors to keep the focus within the factory boundaries. Nonetheless, the reflections are general as they relate the six core characteristics with the production levels.

Table 5 was derived from Table 1 by specifying the production level - either workstation, system and/or factory one - to which the references of Table 1 (recognizable by the identification numbers) referred.

(Table 5 here) 
The majority of authors, when referring to characteristics of reconfigurability, limited their focus on specific systems, indeed they focused at system level. Contrariwise, fewer authors attributed characteristics to the factory level. Moreover, among papers at factory level, almost half of them did not focus on RMSs. Six of them were concerned with changeable manufacturing. Changeability, as observed by Wiendahl et al. (2007), generically represents "characteristics to accomplish early and foresighted adjustments of the factory's structures and processes on all levels to change impulses economically". Thus, changeability can be interpreted as the conceptual extension of reconfigurability beyond the system level.

As detailed in section 3.2, reconfigurability characteristics are related with each other. These relationships can exist not only within production levels, but also across them. Thus, the following analysis - summarised in Table 6 -is on relationships between characteristics across production levels. Indeed:

- a first set of authors (Bruccoleri, Amico and Perrone, 2003; Kannan and Saha, 2009; Bruccoleri, Pasek and Koren, 2006; Landers, Min and Koren, 2001; Spicer, Yip-Hoi and Koren, 2005; Bi et al., 2008a; Kruger and Basson, 2016) allowed evidencing relationships between characteristics at workstation and system levels;

- a second set of authors (Azab and ElMaraghy, 2007; Hees and Reinhart, 2015; Abdi and Labib, 2003; Deif and ElMaraghy, 2007a; Chaube, Benyoucef and Tiwari, 2012; Niroomand, Kuzgunkaya and Bulgak, 2014; Koren, Wang and $\mathrm{Gu}, 2016)$ allowed evidencing relationships between characteristics at system and factory levels; 
- Nejad, Niroomand and Kuzgunkaya (2014) and Niroomand, Kuzgunkaya and Bulgak (2012) allowed evidencing relationships between all three levels, i.e. workstation, system and factory.

(Table 6 here)

The contributions are too exiguous, impeding a generalisation. Nevertheless, a relevant property is remarked by some authors: reconfigurability at lower production levels positively influences reconfigurability at upper production levels (Goyal, Jain, and Jain 2012; Bruccoleri, Nigro and Perrone, 2005; Andersen, Brunoe and Nielsen, 2015). For example, Bruccoleri, Amico, and Perrone (2003) supported the idea that characteristics as integrability, modularity and diagnosability at workstation level (lower level) impact on other characteristics as diagnosability and scalability at system level (upper level).

Thus, starting from the relationships between reconfigurability characteristics in system lifecycle, summarised in Figure 2, further assumptions can be made by superimposing the new dimension, the production levels. Thus, customization should be associated to the highest production levels. Convertibility and scalability, to ensure customization, should be associated, at least, to the highest levels. Modularity, integrability and diagnosability, to ensure scalability and convertibility, should be associated, at least, to the intermediate level.

Overall, it seems reasonable to consider two different options (see Figure 3):

- Option 1: the lowest level to find modularity, integrability and diagnosability is that of workstations. In this case, their presence at workstation level could ensure diagnosability, scalability and convertibility at system level and, therefore, customization at both system and factory/plant level; 
- Option 2: the lowest level to find modularity, integrability and diagnosability is that of systems (Shaik, Rao and Rao, 2014); for instance, in some cases, when dealing with transfer lines and automated assembly lines, the workstations, even if modular from a physical point of view, could not be exploitable for reconfigurability purposes. In this case, the presence of modularity, integrability and diagnosability at system level could ensure diagnosability, scalability and convertibility at factory/plant level and, therefore, customization at factory/plant level.

Obviously, in case of presence of modularity, integrability and diagnosability even at the level of workstations' components, reconfigurability characteristics at higher levels can only be reinforced. In a more general perspective, the existence of modularity, integrability and diagnosability at a given production level, certainly facilitate the formation of modularity, integrability and diagnosability at higher levels.

Within the proposed framework, it can be stated that: (i) having modularity, integrability and diagnosability at a certain level, could allow diagnosability, scalability and convertibility at the next higher level; (ii) having scalability and convertibility at a certain level, could allow customization at both the same and the next higher levels. In addition, comparing options 1 and 2, option 2 is more restrictive: it refers to a case with "less reconfigurability" as all characteristics are shifted to a higher level of aggregation compared to option 1 . In terms of decision making, relating characteristics across production levels makes evident the impacts of decisions made on some characteristics at lower levels on the possible decisions on other characteristics at same or next higher levels.

The figure below (Figure 3) synthesizes the completed version of the framework: 
- the presence of modularity and integrability (configuration characteristics) should impact on scalability and convertibility; to ensure the customization of the plant, they should be associated, at least, to the system level (option 2);

- diagnosability (configuration characteristic) should be favoured by modularity and integrability; moreover, it should make effective scalability and convertibility (acting on the ramp-up time); to make effective the customization of the plant, it should be associated, at least, to the system level (option 2);

- scalability and convertibility (reconfiguration characteristics), should impact on customization; to ensure the customization of the plant, they should be associated, at least, to the factory level (option 2).

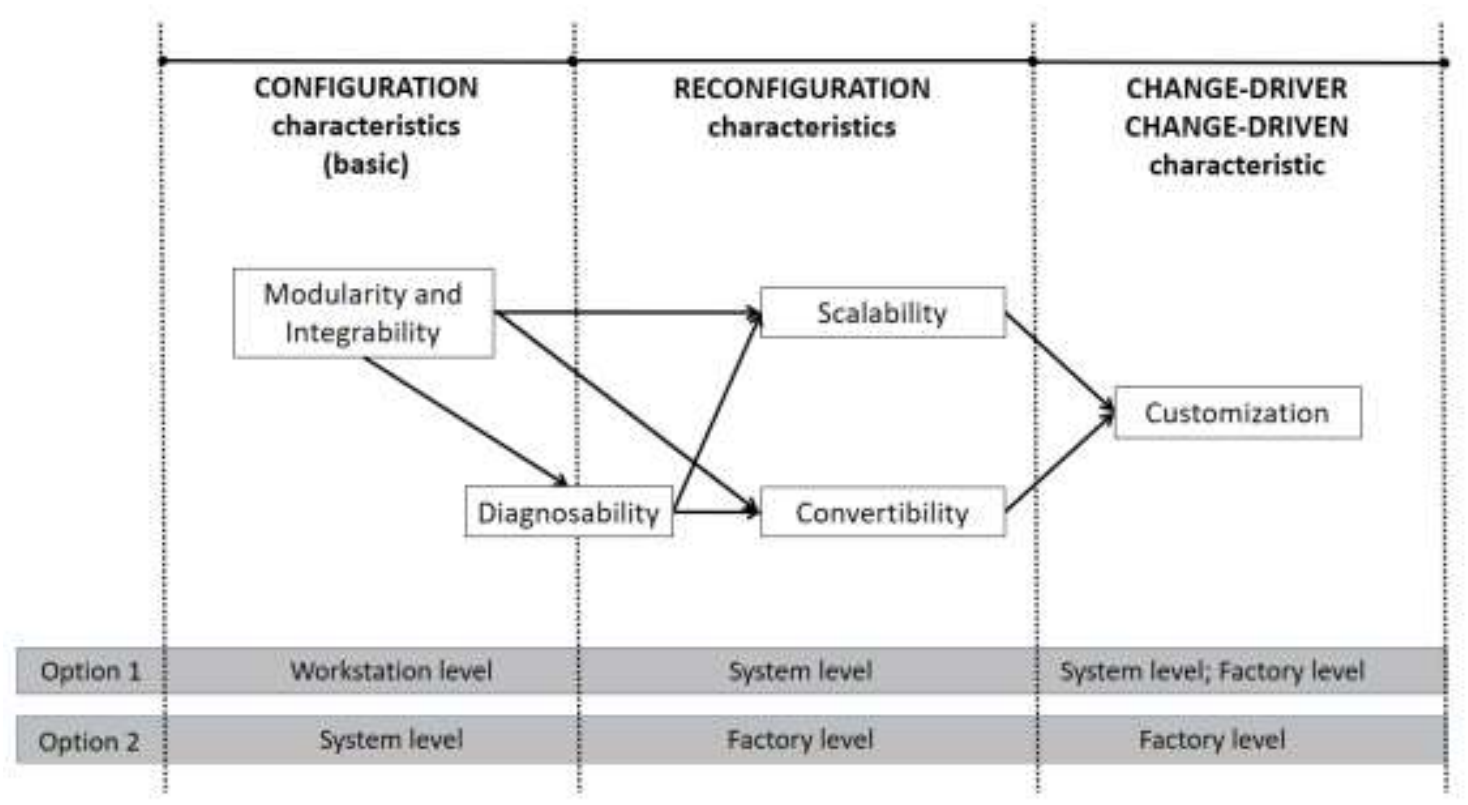

Figure 3 A general framework to manage reconfigurability in manufacturing

\subsection{Concluding remarks}

This section answered to RQs2. Figure 3 synthetizes the proposed framework to manage reconfigurability in manufacturing. The six core characteristics of reconfigurability are analyzed within two dimensions: along system lifecycle and across production levels. The 
framework allows revealing common decision making structures to use reconfigurability as enabler of responsiveness of manufacturing firms. Indeed, strategic decision making should exploit customization as a change driver characteristic. Thus, during the configuration stage of system lifecycle, design choices - in terms of modularity, integrability and diagnosability - at lower production levels would simplify operational decisions - in terms of scalability, convertibility and diagnosability - at upper levels.

The framework is then proposed as a simple and general reference model to drive further developments for the management of reconfigurability in manufacturing. It means a number of implications, remarked in the concluding section, also referring to future researches.

\section{Conclusions}

This paper proposes a general framework to manage reconfigurability as a capability.

After an introduction where reconfigurability is presented as a necessary capability for manufacturing firms to compete in the current competitive scenario, the paper is structured as a journey that, exploiting the available literature, allows progressively building the framework. More in detail, literature insights have been gathered, combined and reorganized following a specific sequence of steps, leading to a progressive construction of the framework. At first, literature has been exploited to take note of the six core characteristics of reconfigurability. Secondly, it has been remarked the reason for the relevance of the characteristics, in terms of reconfiguration time, reconfiguration cost and ramp-up time. Thirdly, further literature review has allowed classifying the characteristics, according to their role within different periods of system lifecycle. Fourthly, by studying their relationships, it has been explained, how the six characteristics can be exploited. Then, literature has been used to place the characteristics 
and their relationships at different production levels, completing the framework with a space dimension, besides the time dimension given by system lifecycle.

The framework is a holistic attempt to exploit different and scattered insights of literature. It relates the six characteristics with each other while, quite often, literature doesn't explicitly address these relationships and, above all, not in a comprehensive way. It provides a specific consolidation of the relationships between characteristics associating them to production levels; indeed this aspect is just partially, and more or less implicitly, discussed in literature.

Overall, this research made a theoretical step, which has led to the proposal of a general framework. Future exploitation of reconfigurability as a concept together with insights coming from the practical reality could allow enriching the framework with detailed variables, in order to build a "tool" that allows manufacturing firms exploiting the reconfigurability capability. To this end, further research should aim at identifying external conditions which may influence the framework. Indeed, as stressed by Sousa and Voss (2008), operations practices are not universally valid, but efforts should be made to identify the contextual conditions under which practices are effective. Thus, the enrichment of the framework should start with the identification of external elements and their relationships with the core characteristics. Moreover, from an internal perspective, future development of this research could also include further investigation on the kind of relationships between characteristics, in order to understand if some of them are more important than others and to investigate more on the different typologies of possible relationships. This may require empirical evidences gathered through field researches in different industrial settings (e.g. either large or small and medium sized companies, as well as different industry sectors). 
In terms of implications for managerial issues, a number of possible evolutions can be considered, all achievable bridging the theory given by the framework with the practical needs. Building on the two dimensions indicated in the framework (i.e. system lifecycle and production levels) for the exploitation of reconfigurability characteristics (i.e. the six core characteristics), three research streams can be, at least, envisioned: (i) the development of methodologies for an holistic approach to manage reconfigurability in manufacturing; (ii) the structured organization of reconfigurability-related knowledge, i.e. theoretical and practical knowledge; (iii) the investigation on the role of the technologies due to the currently on-going Fourth Industrial Revolution, with a particular emphasis on their effects on reconfigurability as a capability. Bounded to the scope of the first research stream, currently the authors intend to make a study to develop a holistic performance measurement system of reconfigurability as a capability.

\section{References}

Abbasi, M., and M. Houshmand. 2009. "Production Planning of Reconfigurable Manufacturing Systems with Stochastic Demands Using Tabu Search." International Journal of Manufacturing Technology and Management 17 (1-2): 125-48. doi:10.1504/IJMTM.2009.023782.

Abbasi, M., and M. Houshmand. 2011. "Production Planning and Performance Optimization of Reconfigurable Manufacturing Systems Using Genetic Algorithm." International Journal of Advanced Manufacturing Technology 54 (1-4): 373-92. doi:10.1007/s00170-010-2914-x.

Abdi, M. R. 2009. "Fuzzy Multi-Criteria Decision Model for Evaluating Reconfigurable Machines.” International Journal of Production Economics 117 (1): 1-15.

Abdi, M. R., and A. W. Labib. 2003. "A Design Strategy for Reconfigurable Manufacturing Systems (RMSs) Using Analytical Hierarchical Process (AHP): A Case Study.” International Journal of Production Research 41 (10): 2273-99. doi:10.1080/0020754031000077266.

Abdi, M. R., and A. W. Labib. 2004a. "Feasibility Study of the Tactical Design Justification for Reconfigurable Manufacturing Systems Using the Fuzzy 
Analytical Hierarchical Process." International Journal of Production Research 42 (15): 3055-76. doi:10.1080/00207540410001696041.

Abdi, M. R., and A. W. Labib. 2004b. "Grouping and Selecting Products: The Design Key of Reconfigurable Manufacturing Systems (RMSs).” International Journal of Production Research 42 (3): 521-46. doi:10.1080/00207540310001613665.

Abdi, Mohammad Reza, and Ashraf W. Labib. 2017. RMS capacity utilisation: product family and supply chain, International Journal of Production Research, 55(7): 1930-1956, DOI:10.1080/00207543.2016.1229066

Aboufazeli, N. 2011. "Reconfigurable Machine Tools Design Methodologies and Measuring Reconfigurability for Design Evaluation.”

Aguilar, A., A. Roman-Flores, and J. C. Huegel. 2013. "Design, Refinement, Implementation and Prototype Testing of a Reconfigurable Lathe-Mill.” Journal of Manufacturing Systems 32 (2): 364-71. doi:10.1016/j.jmsy.2013.01.003.

Andersen, A. L., T. D. Brunoe, and K. Nielsen. 2015. "Reconfigurable Manufacturing on Multiple Levels: Literature Review and Research Directions.” In: Advances in Production Management Systems: Innovative Production Management Towards Sustainable Growth, 266-73.

Ayman, M, M. Youssef, and H. A. ElMaraghy. 2006. “Assessment of Manufacturing Systems Reconfiguration Smoothness." International Journal of Advanced Manufacturing Technology 30 (1-2): 174-93. doi:10.1007/s00170-005-0034-9.

Azab, A., and H. A. ElMaraghy. 2007. "Sequential Process Planning: A Hybrid Optimal Macro-Level Approach.” Journal of Manufacturing Systems 26 (3-4): 147-60. doi:10.1016/j.jmsy.2008.03.003.

Azevedo, M. M., J. A. Crispim, and J. P. de Sousa. 2017. “A Dynamic Multi-Objective Approach for the Reconfigurable Multi-Facility Layout Problem.” Journal of Manufacturing Systems 42: 140-52. doi:10.1016/j.jmsy.2016.12.008.

Bensmaine, A., M Dahane, and L. Benyoucef. 2013. "A Non Dominated Sorting Genetic Algorithm Based Approach for Optimal Machines Selection in Reconfigurable Manufacturing Environment." Computers \& Industrial Engineering. Advance online publication. doi:10.1016/j.cie.2012.09.008.

Bi, Z. M., S. Y. T. Lang, W. Shen, and L. Wang. 2008a. "Reconfigurable Manufacturing Systems: The State of the Art.” International Journal of Production Research 46 (4): 967-92. doi:10.1080/00207540600905646. 
Bi, Z. M., Y. Sherman, T. Lang, M. Verner, and P. Orban. 2008b. "Development of Reconfigurable Machines." International Journal of Advanced Manufacturing Technology 39 (11-12): 1227-51. doi:10.1007/s00170-007-1288-1.

Bi, Z. M. 2011. "Revisiting System Paradigms from the Viewpoint of Manufacturing Sustainability.” Sustainability 3 (9): 1323-40. doi:10.3390/su3091323.

Borisovsky, P. A., X. Delorme, and A. Dolgui. 2014. Balancing reconfigurable machining lines via a set partitioning model, International Journal of Production Research 52 (13): 4026-4036. doi:10.1080/00207543.2013.849857

Bruccoleri, M., M. Amico, and G. Perrone. 2003. "Distributed Intelligent Control of Exceptions in Reconfigurable Manufacturing Systems." International Journal of Production Research 41 (7): 1393-1412. doi:10.1080/1352816031000075170.

Bruccoleri, M., G. Lo Nigro, G. Perrone, P. Renna, and S. Noto La Diega. 2005. "Production Planning in Reconfigurable Enterprises and Reconfigurable Production Systems." CIRP Annals - Manufacturing Technology 54 (2): 433-36. doi:10.1016/S0007-8506(07)60138-3.

Bruccoleri, M., Z. J. Pasek, and Y. Koren. 2006. "Operation Management in Reconfigurable Manufacturing Systems: Reconfiguration for Error Handling." International Journal of Production Economics 100 (1): 87-100. doi:10.1016/j.ijpe.2004.10.009.

Cao, Y., H. A. ElMaraghy, and A. Azab. 2007. "Reconfigurable Control Structure for Robots in Assembly." Journal of Intelligent and Robotic Systems: Theory and Applications 50 (4): 419-39. doi:10.1007/s10846-007-9173-6.

Carpanzano, E., A. Cesta, A. Orlandini, R. Rasconi, M. Suriano, A. Umbrico, and A. Valente. 2016. "Design and Implementation of a Distributed Part-Routing Algorithm for Reconfigurable Transportation Systems.” International Journal of Computer Integrated Manufacturing $29 \quad$ (12): 1317-34. doi:10.1080/0951192X.2015.1067911.

Chaube, A., L. Benyoucef, and M. K. Tiwari. 2012. “An Adapted NSGA-2 Algorithm Based Dynamic Process Plan Generation for a Reconfigurable Manufacturing System." Journal of Intelligent Manufacturing 23 (4): 1141-55. doi:10.1007/s10845-010-0453-9.

Crama, Y., Y. Pochet, and Y. Wera. 2001. "A Discussion of Production Planning Approaches in the Process Industry." CORE Discussion Papers 7 (2001): 1-33. 
Deif, A. M., and W. H. ElMaraghy. 2006. “A Control Approach to Explore the Dynamics of Capacity Scalability in Reconfigurable Manufacturing Systems." Journal of Manufacturing Systems 25 (1): 12-24. doi:10.1016/S0278-6125(07)00003-9.

Deif, A. M., and H. A. ElMaraghy. 2007a. “Assessing Capacity Scalability Policies in RMS Using System Dynamics.” International Journal of Flexible Manufacturing Systems 19 (3): 128-50. doi:10.1007/s10696-008-9031-2.

Deif, A. M., and W. H. ElMaraghy. 2007b. "Investigating Optimal Capacity Scalability Scheduling in a Reconfigurable Manufacturing System.” International Journal of Advanced Manufacturing Technology 32 (5-6): 557-62. doi:10.1007/s00170005-0354-9.

Dhupia, J., B. Powalka, R. Katz, and A. G. Ulsoy. 2007. "Dynamics of the Arch-Type Reconfigurable Machine Tool.” International Journal of Machine Tools and Manufacture 47 (2): 326-34. doi:10.1016/j.ijmachtools.2006.03.017.

Dou, J., X. Dai, and Z. Meng. 2010. “Optimisation for Multi-Part Flow-Line Configuration of Reconfigurable Manufacturing System Using GA." International Journal of Production Research 48 (14): 4071-4100. doi:10.1080/00207540903036305.

Dubey, R., A. Gunasekaran, and A. Chakrabarty. 2015. World-class sustainable manufacturing: framework and a performance measurement system, International Journal of Production Research 53 (17): 5207-5223. doi:10.1080/00207543.2015.1012603

Dubey, R., A. Gunasekaran, P. Helo, T. Papadopoulos, S. J. Childe and, B. S. Sahay. 2017. Explaining the impact of reconfigurable manufacturing systems on environmental performance: The role of top management and organizational culture. Journal of Cleaner Production 141: 56-66. https://doi.org/10.1016/j.jclepro.2016.09.035

ElMaraghy, H. A. 2006. "Flexible and Reconfigurable Manufacturing Systems Paradigms." Flexible Services and Manufacturing Journal 17 (4): 261-76. doi:10.1007/s10696-006-9028-7.

ElMaraghy, H. A. 2007. "Reconfigurable Process Plans for Responsive Manufacturing Systems.” Digital Enterprise Technology 35-44. doi:10.1007/978-0-387-498645_4. 
ElMaraghy, H. A. 2009. "Changing and Evolving Products and Systems - Models and Enablers." Changeable and Reconfigurable Manufacturing Systems 25-45. doi:10.1007/978-1-84882-067-8_2.

Essafi, M., X. Delorme and A. Dolgui. 2012. "A reactive GRASP and Path Relinking for balancing reconfigurable transfer lines." International Journal of Production Research 50 (18): 5213-5238. doi: 10.1080/00207543.2012.677864

Farid, A. M. 2014. "Measures of Reconfigurability and Its Key Characteristics in Intelligent Manufacturing Systems.” Journal of Intelligent Manufacturing 28 (2): 353-69. doi:10.1007/s10845-014-0983-7.

Fredriksson, P. 2006. "Mechanisms and rationales for the coordination of a modular assembly system." International Journal of Operations \& Production Management 26 (4): 350-70. doi:10.1108/02656710210415703.

Freiheit, T., M. Shpitalni, S. J. Hu, and Y. Koren. 2004. "Productivity of synchronized serial production lines with flexible reserve capacity." International Journal of Production $\quad$ Research 42 (10): 2009-2027. https://doi.org/10.1081/00207540310001647596

Galan, R., J. Racero, I. Eguia, and J. M. Garcia. 2007. “A Systematic Approach for Product Families Formation in Reconfigurable Manufacturing Systems." Robotics and Computer-Integrated Manufacturing. doi:10.1016/j.rcim.2006.06.001.

Garbie, I. H. 2014. "An analytical technique to model and assess sustainable development index in manufacturing enterprises." International Journal of Production Research 52 (16): 4876-4915. doi: 10.1080/00207543.2014.893066

Garetti, M., L. Fumagalli, and E. Negri. 2015. "Role of Ontologies for CPS Implementation in Manufacturing." MPER - Management and Production Engineering Review 6 (4): 26-32. doi:10.1515/mper-2015-0033.

Goyal, K. K., P.K. Jain, and M. Jain. 2013. “A Comprehensive Approach to Operation Sequence Similarity Based Part Family Formation in the Reconfigurable Manufacturing System.” International Journal of Production Research 51 (6): 1762-1776. doi:10.1080/00207543.2012.701771.

Goyal, K. K., P. K. Jain, and M. Jain. 2012. "Optimal Configuration Selection for Reconfigurable Manufacturing System Using NSGA II and TOPSIS." International Journal of Production Research 50 (15): 4175-91. doi:10.1080/00207543.2011.599345. 
Gu, X., X. Jin, J. Ni, and Y. Koren. 2015. "Manufacturing system design for resilience.” Procedia CIRP 36: 135-140. https://doi.org/10.1016/j.procir.2015.02.075.

Gumasta, K., S. Kumar Gupta, L. Benyoucef, and M. K. Tiwari. 2011. "Developing a Reconfigurability Index Using Multi-Attribute Utility Theory.” International Journal of Production Research 49 (6): 1669-83. doi:10.1080/00207540903555536.

Haddou Benderbal, H., Hichem, M. Dahane and L. Benyoucef. 2017. "Flexibility-based multi-objective approach for machines selection in reconfigurable manufacturing system (RMS) design under unavailability constraints." International Journal of Production Research, 55 (20): 6033-6051. doi: 10.1080/00207543.2017.1321802

Hasan, F., P. K. Jain, and D. Kumar. 2014. "Performance Issues in Reconfigurable Manufacturing System.” DAAAM International Scientific Book 2014 295-310. doi:10.2507/daaam.scibook.2014.24.

Hees, A., and G. Reinhart. 2015. "Approach for Production Planning in Reconfigurable Manufacturing Systems." Procedia CIRP 33: 70-75. doi:10.1016/j.procir.2015.06.014.

Heisel, U., and M. Meitzner. 2006. "Progress in Reconfigurable Manufacturing Systems." Reconfigurable Manufacturing Systems and Transformable Factories 47-62. doi:10.1007/3-540-29397-3_4.

Kannan, M., and J. Saha. 2009. "A Feature-Based Generic Setup Planning for Configuration Synthesis of Reconfigurable Machine Tools." International Journal of Advanced Manufacturing Technology 43 (9-10): 994-1009. doi:10.1007/s00170-008-1779-8.

Katz, R. 2007. "Design Principles of Reconfigurable Machines.” International Journal of Advanced Manufacturing Technology 34 (5-6): 430-39. doi:10.1007/s00170006-0615-2.

Koren, Y, U Heisel, J Jovane, T Moriwaki, G Pritschow, G Ulsoy, and H Van Brussel. 1999. "Reconfigurable Manufacturing Systems." CIRP Annals--Manufacturing Technology.

Koren, Y., and G. Ulsoy. 2002. "Reconfigurable Manufacturing System Having A production Capacity Method for Designing Same and Method for Changing Its Production Capacity” 1 (12): 26. http://www.google.com/patents/US6349237.

Koren, Y., and R. Katz. 2003. Reconfigurable apparatus and method for inspection during a manufacturing process. US Patent 6567162, May 20. 
Koren, Y. 2005. "Reconfigurable Manufacturing and Beyond." In 3rd International Conference on Reconfigurable Manufacturing, 1-7.

Koren, Y. 2006. "General RMS Characteristics. Comparison with Dedicated and Flexible Systems" Chapter 3 in Reconfigurable Manufacturing Systems and Transformable Factories, 27-45. doi: 10.1007/3-540-29397-3_3

Koren, Y. 2010. "The Global Manufacturing Revolution: Product-Process-Business Integration and Reconfigurable Systems," Hoboken: John Wiley \& Sons.

Koren, Y., and M. Shpitalni. 2010. "Design of Reconfigurable Manufacturing Systems.” Journal of Manufacturing Systems 29 (4): 130-41. doi:10.1016/j.jmsy.2011.01.001.

Koren, Y. 2013. "The Rapid Responsiveness of RMS." International Journal of Production Research 51 (23-24): 6817-27. doi:10.1080/00207543.2013.856528.

Koren, Y. 2014. "Reconfigurable Manufacturing System.” In CIRP Encyclopedia of Production Engineering, 1035-39. doi:10.1007/978-3-642-20617-7.

Koren, Y., W. Wang, and X. Gu. 2016. "Value Creation through Design for Scalability of Reconfigurable Manufacturing Systems." International Journal of Production Research, 1-16. doi:10.1080/00207543.2016.1145821.

Kruger, K., and A. Basson. 2016. "Erlang-Based Control Implementation for a Holonic Manufacturing Cell." International Journal of Computer Integrated Manufacturing $30 \quad$ (6). Taylor \& $\quad$ Francis: 1-12. doi:10.1080/0951192X.2016.1195923.

Kuo, C. H. 2001. "Resource Allocation and Performance Evaluation of the Reconfigurable Manufacturing Systems." International Conference on Systems, Man and Cybernetics, 2451-56. http://dx.doi.org/10.1109/ICSMC.2001.972925.

Kusiak, A. 2002. "Integrated Product and Process Design: A Modularity Perspective." Journal of Engineering Design $13 \quad$ (3): 223-31. doi:10.1080/09544820110108926.

Landers, R. G., B. Min, and Y. Koren. 2001. "Reconfigurable Machine Tools." In CIRP Annals - Manufacturing Technology, 269-74.

Lastra, J. L. M., and M. Delamer. 2006. "Semantic Web Services in Factory Automation: Fundamental Insights and Research Roadmap.” IEEE Transactions on Industrial Informatics 2 (1): 1-11. doi:10.1109/TII.2005.862144. 
Leitão, P., J. Barbosa, and D. Trentesaux. 2012. "Bio-Inspired Multi-Agent Systems for Reconfigurable Manufacturing Systems.” Engineering Applications of Artificial Intelligence 25 (5): 934-44. doi:10.1016/j.engappai.2011.09.025.

Liu, J. P., Z. B. Luo, L. K. Chu, and Y. L. Chen. 2004. "Manufacturing System Design with Optimal Diagnosability.” International Journal of Production Research 42 (9): 1695-1714. doi:10.1080/00207540310001645147.

Makinde, O. A., K. Mpofu, and A. P. I. Popoola. 2014. "Review of the Status of Reconfigurable Manufacturing Systems (RMS) Application in South Africa Mining Machinery Industries." Procedia CIRP 17: 136-41. doi:10.1016/j.procir.2014.02.035.

Mehrabi, M., G. Ulsoy, A. G. and Y. Koren. 2000a. Reconfigurable manufacturing systems and their enabling technologies. 1-21.

Mehrabi, M., G. Ulsoy, A. G. and Y. Koren. 2000b. "Reconfigurable Manufacturing Systems: Key to Future Manufacturing.” Journal of Intelligent Manufacturing 11 (4): 403-419.

Mehrabi, M. G., and E. Kannatey-Asibu. 2001. "Mapping Theory: A New Approach to Design of Multi-Sensor Monitoring of Reconfigurable Machining Systems (RMS).” Journal of Manufacturing Systems 20: 297-304. doi:10.1016/S02786125(01)80049-2.

Meng, X. 2010. "Modeling of Reconfigurable Manufacturing Systems Based on Colored Timed Object-Oriented Petri Nets.” Journal of Manufacturing Systems 29 (2-3): 81-90. doi:10.1016/j.jmsy.2010.11.002.

Mesa, J., H. Maury, J. Turizo, and A. Bula. 2014. "A Methodology to Define a Reconfigurable System Architecture for a Compact Heat Exchanger Assembly Machine.” International Journal of Advanced Manufacturing Technology 70 (912): 2199-2210. doi:10.1007/s00170-013-5451-6.

Molina, A., C. A. Rodriguez, H. Ahuett, J. A. Cortés, M. Ramírez, G. Jiménez, and S. Martinez. 2005. "Next-Generation Manufacturing Systems: Key Research Issues in Developing and Integrating Reconfigurable and Intelligent Machines." International Journal of Computer Integrated Manufacturing 18 (7): 525-36. doi:10.1080/09511920500069622.

Moon, Y. M., and S. Kota. 2002. "Generalized Kinematic Modeling of Reconfigurable Machine Tools." Journal of Mechanical Design, Transactions of the ASME 124 (1): 47-51. doi:10.1115/1.1424892. 
Müller, C., Grunewald, M., and Spengler, T. S. 2017. "Redundant configuration of automated flow lines based on "Industry 4.0"-technologies." Journal of Business Economics 87 (7): 877-898. https://doi.org/10.1007/s11573-016-0831-7

Negri, E., L. Fumagalli, M. Garetti, and L. Tanca. 2016. "Requirements and Languages for the Semantic Representation of Manufacturing Systems." Computers in Industry 81 (C): 55-66. doi:10.1016/j.compind.2015.10.009.

Nejad, A. E., I. Niroomand, and O. Kuzgunkaya. 2014. "Responsive Contingency Planning in Supply Risk Management by Considering Congestion Effects.” Omega (United Kingdom) 48. Elsevier: 19-35. doi:10.1016/j.omega.2014.03.002.

Niroomand, I., O. Kuzgunkaya, and A. A. Bulgak. 2012. "Impact of Reconfiguration Characteristics for Capacity Investment Strategies in Manufacturing Systems.” International Journal of Production Economics 139 (1): 288-301. doi:10.1016/j.ijpe.2012.05.012.

Niroomand, I., O. Kuzgunkaya, and A. A. Bulgak. 2014. "The Effect of System Configuration and Ramp-up Time on Manufacturing System Acquisition under Uncertain Demand." Computers and Industrial Engineering 73 (1): 61-74. doi:10.1016/j.cie.2014.04.017.

Pérez Rodriguez, R., J. Aca S., A. Valverde T., H. Ahuett G., A. Molina G., and C. Riba R. 2004. "A Modularity Framework for Concurrent Design of Reconfigurable Machine Tools". In International Conference on Cooperative Design, Visualization, and Engineering 3190: 87-95. doi:10.1007/978-3-540-301035_10.

Prasad, D.a and S. C. Jayswal. 2017. Reconfigurability consideration and scheduling of products in a manufacturing industry, International Journal of Production Research, DOI: 10.1080/00207543.2017.1334979

Pugliese, V., J. Mesa, and H. Maury. 2016. "Development of a Design Methodology for Reconfigurable Injection Molds." International Journal of Advanced Manufacturing Technology. The International Journal of Advanced Manufacturing Technology, 1-14. doi:10.1007/s00170-016-9348-z.

Puik, E., D. Telgen, L. Van Moergestel, and D. Ceglarek. 2016. “Assessment of Reconfiguration Schemes for Reconfigurable Manufacturing Systems Based on Resources and Lead Time." Robotics and Computer-Integrated Manufacturing 43 (2017): 30-38. doi:10.1016/j.rcim.2015.12.011. 
Rehman, A.-U. and A. Subash Babu. 2013. "Reconfigurations of Manufacturing Systems - An Empirical Study on Concepts, Research, and Applications.” International Journal of Advanced Manufacturing Technology 66 (1-4): 107-24. doi:10.1007/s00170-012-4310-1.

Renna, P. 2010. "Capacity Reconfiguration Management in Reconfigurable Manufacturing Systems." International Journal of Advanced Manufacturing Technology 46 (1-4): 395-404. doi:10.1007/s00170-009-2071-2.

Reza Abdi, M. 2009. "Layout Configuration Selection for Reconfigurable Manufacturing Systems Using the Fuzzy AHP." International Journal of Manufacturing Technology and Management 17 (1): 149. doi:10.1504/IJMTM.2009.023783.

Ribeiro, L., and J. Barata. 2011. "Re-Thinking Diagnosis for Future Automation Systems: An Analysis of Current Diagnostic Practices and Their Applicability in Emerging IT Based Production Paradigms." Computers in Industry 62 (7): 639-59. doi:10.1016/j.compind.2011.03.001.

Rösiö, C. 2011. Considering Reconfigurability Characteristics in Production System Design. In Enabling Manufacturing Competitiveness and Economic Sustainability: Proceedings of the 4th International Conference on Changeable, Agile, Reconfigurable and Virtual production (CARV2011), Montreal, Canada, 2-5 October 2011 (pp. 57-62). https://doi.org/10.1007/978-3-642-23860-4_9

Rösiö, C. 2012. Supporting the Design of Reconfigurable Production Systems. Mälardalen University Press PhD Dissertations. http://www.divaportal.org/smash/record.jsf?pid=diva2:591325.

Rösiö, C., and K. Säfsten. 2013. "Reconfigurable Production System Design Theoretical and Practical Challenges." Journal of Manufacturing Technology Management 24 (7): 998-1018. doi:10.1108/JMTM-02-2012-0021.

Saxena, L. K., and P. K. Jain. 2012. "A Model and Optimisation Approach for Reconfigurable Manufacturing System Configuration Design." International Journal of Production Research 50 (12): 3359-81. doi:10.1080/00207543.2011.578161.

Scholz-Reiter, B., D. Lappe, and S. Grundstein. 2015. "Capacity Adjustment Based on Reconfigurable Machine Tools - Harmonising Throughput Time in Job-Shop Manufacturing." CIRP Annals - Manufacturing Technology. 64 (1): 403-406. doi:10.1016/j.cirp.2015.04.104. 
Scholz, Steffen, Tobias Mueller, Matthias Plasch, Hannes Limbeck, Raphael Adamietz, Tobias Iseringhausen, Daniel Kimmig, Markus Dickerhof, and Christian Woegerer. 2016. “A Modular Flexible Scalable and Reconfigurable System for Manufacturing of Microsystems Based on Additive Manufacturing and EPrinting." Robotics and Computer-Integrated Manufacturing 40 (August). Elsevier: 14-23. doi:10.1016/j.rcim.2015.12.006.

Setchi, R. M., and N. Lagos. 2004. "Reconfigurability and Reconfigurable Manufacturing Systems - State-of-the-Art Review." In IEEE International Conference on Industrial Informatics Berlin: IEEE. doi:10.1109/INDIN.2004.1417401.

Shabaka, A. I., and H. A. ElMaraghy. 2007. "Generation of Machine Configurations Based on Product Features." International Journal of Computer Integrated Manufacturing 20 (4): 355-69. doi:10.1080/09511920600740627.

Shah, Nilay. 2005. "Process Industry Supply Chains: Advances and Challenges." Computers and Chemical Engineering 29 (6): 1225-1235. doi:10.1016/j.compchemeng.2005.02.023.

Shaik, A. M., V. V. S. Kesava Rao, and C. S. Rao. 2014. "Development of Modular Manufacturing Systems - a Review." International Journal of Advanced Manufacturing Technology 76 (5-8): 789-802. doi:10.1007/s00170-014-6289-2.

Silva Belisario, L, and H Pierreval. 2013. “A Conceptual Framework for Analyzing Adaptable and Reconfigurable Manufacturing Systems.” In Proceedings of 2013 International Conference on Industrial Engineering and Systems Management Rabat: IEEE.

Singh, R. K., N. Khilwani, and M. K. Tiwari. 2007. "Justification for the Selection of a Reconfigurable Manufacturing System: A Fuzzy Analytical Hierarchy Based Approach.” International Journal of Production Research 45 (14): 3165-90. doi:10.1080/00207540600844043.

Son, S. Y., T. L. Olsen, and D. Yip-Hoi. 2001. "An Approach to Scalability and Line Balancing for Reconfigurable Manufacturing Systems." Integrated Manufacturing Systems 12 : 500-511. doi:10.1108/09576060110407815.

Sousa, R., and Voss, C. A. 2008. Contingency research in operations management practices. Journal of Operations Management, 26(6): 697-713.

Spicer, P., D. Yip-Hoi, and Y. Koren. 2005. "Scalable Reconfigurable Equipment Design Principles." International Journal of Production Research 43 (22): 4839-52. doi:10.1080/00268970500183042. 
Spicer, P., and H. J. Carlo. 2007. "Integrating Reconfiguration Cost Into the Design of Multi-Period Scalable Reconfigurable Manufacturing Systems." Journal of Manufacturing Science and Engineering 129 (1): 202. doi:10.1115/1.2383196.

Stoian, C., and Ga. Frumuşanu. 2007. "Reconfigurable Manufacturing Systems Design Principles Researchers." The annals "Dunareae de jos" of galati fascicle $v$, Technologies in Mechanical Engineering 62-65.

Tang, Y., and R. G. Qiu. 2004. "Integrated Design Approach for Virtual Production LineBased Reconfigurable Manufacturing Systems." International Journal of Production Research 42 (18): 3803-22. doi:10.1080/00207540410001699372.

Unglert, J., S. Hoekstra, J. Jauregui-Becker, and F. Van Houten. 2016. "Towards Decision-Support for Reconfigurable Manufacturing Systems Based on Computational Design Synthesis." Procedia CIRP 41: 153-58. doi:10.1016/j.procir.2015.12.053.

Vafadar, A., M. Tolouei-Rad, K. Hayward, and K. Abhary. 2016. "Technical Feasibility Analysis of Utilizing Special Purpose Machine Tools." Journal of Manufacturing Systems 39 : 53-62. doi:10.1016/j.jmsy.2016.02.003.

Vafadar, A., K. Hayward and M. Tolouei-Rad. 2017. "Sensitivity analysis for justification of utilising special purpose machine tools in the presence of uncertain parameters." International Journal of Production Research 55(13): 3842-3861. doi:10.1080/00207543.2017.1308032

Valente, A. 2016. "Reconfigurable Industrial Robots: A Stochastic Programming Approach for Designing and Assembling Robotic Arms." Robotics and Computer-Integrated Manufacturing 41: 115-26. doi:10.1016/j.rcim.2016.03.002.

Wang, W., and Y. Koren. 2012. "Scalability Planning for Reconfigurable Manufacturing Systems." Journal of Manufacturing Systems $31 \quad$ (2): 83-91. doi:10.1016/j.jmsy.2011.11.001.

Weng, Y., X. He, and Z. Pan. 2017. "Space Division Multiplexing Optical Communication Using Few-Mode Fibers." Optical Fiber Technology 36. Elsevier Inc.: 155-80. doi:10.1016/j.yofte.2017.03.009.

Wiendahl, H. P., H. A. ElMaraghy, P. Nyhuis, M. F. Zah, H. H. Wiendahl, N. Duffie, and M. Brieke. 2007. "Changeable Manufacturing - Classification, Design and Operation." CIRP Annals - Manufacturing Technology 56 (2): 783-809. doi:10.1016/j.cirp.2007.10.003. 
Wu, D., D. W. Rosen, L. Wang, and D. Schaefer. 2015. "Cloud-Based Design and Manufacturing: A New Paradigm in Digital Manufacturing and Design Innovation." CAD Computer Aided Design 59: 1-14. doi:10.1016/j.cad.2014.07.006.

Yan, J. and V. Vyatkin. 2013. "Distributed Software Architecture Enabling Peer-to-Peer Communicating Controllers". IEEE Transactions on Industrial Informatics 9 (4): 2200-2209.

Yu, J., Y. Yin, X. Sheng, Z. Chen. 2003. "Modelling strategies for reconfigurable assembly systems", Assembly Automation, 23 (3): 266-272. https://doi.org/10.1108/01445150310486530

Yu, M., W. Zhang, and P. Klemm. 2007. "Multi-Agent Based Reconfigurable Manufacturing Execution System.” 2007 IEEE International Conference on Industrial Engineering and Engineering Management 718-22. doi:10.1109/IEEM.2007.4419284.

Zhang, G., R. Liu, L. Gong, and Q. Huang. 2006. "An Analytical Comparison on Cost and Performance among DMS, AMS, FMS and RMS." Chapter in Reconfigurable Manufacturing Systems and Transformable Factories, 659-673. doi:10.1007/3540-29397-3_33.

Zhang, J., M. Khalgui, Z. Li, G. Frey, O. Mosbahi, and H. B. Salah. 2015. "Reconfigurable Coordination of Distributed Discrete Event Control Systems." IEEE Transactions on Control Systems Technology 23 (1): 323-30. doi:10.1109/TCST.2014.2313352.

Zhang, J., F. T. S. Chan, P. Li, H. C. W. Lau, R. W. L. Ip, and P. Samaranayak. 2002. "Investigation of the Reconfigurable Control System for an Agile Manufacturing Cell." International Journal of Production Research 40 : 3709-23. doi:10.1080/00207540210159554.

Zhang, Linda L., Qianli Xu, Yugang Yu, and Roger J. Jiao. 2012. "Domain-Based Production Configuration with Constraint Satisfaction." International Journal of Production Research 50 (24): 7149-66. doi:10.1080/00207543.2011.640714.

Zhang, Y., G. Q. Huang, Q. Y. Dai, O. Ho, and F. J. Xu. 2010. “Agent-Based Workflow Management for RFID-Enabled Real-Time Reconfigurable Manufacturing." International Journal of Computer Integrated Manufacturing 3052: 341-64. doi:10.1007/978-1-84882-287-0_14. 

Table 1 Reconfigurability characteristics

\begin{tabular}{|c|c|c|c|c|c|c|c|c|c|c|c|c|c|}
\hline 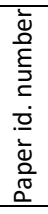 & Authors & $\begin{array}{l}\frac{\vec{z}}{\frac{\pi}{\pi}} \\
\frac{\pi}{5} \\
\frac{\overline{0}}{0} \\
\sum\end{array}$ & 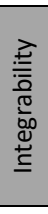 & 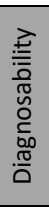 & 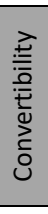 & $\begin{array}{l}\frac{\vec{Z}}{\overline{0}} \\
\frac{\pi}{\sqrt{0}} \\
\stackrel{心}{n}\end{array}$ & 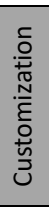 & 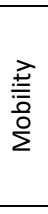 & 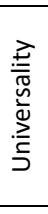 & 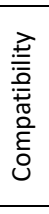 & 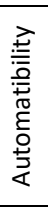 & 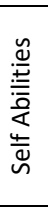 & $\begin{array}{l}\frac{\vec{E}}{\overline{\frac{a}{a}}} \\
\frac{\mathbb{a}}{4}\end{array}$ \\
\hline 1 & Koren et al. (1999) & $\mathrm{x}$ & $\mathrm{x}$ & $\mathrm{x}$ & $\mathrm{x}$ & & $\mathrm{x}$ & & & & & & \\
\hline 2 & $\begin{array}{l}\text { Mehrabi, Ulsoy and Koren } \\
\text { (2000a) }\end{array}$ & $\mathrm{x}$ & $\mathrm{x}$ & $\mathrm{x}$ & $\mathrm{x}$ & & $\mathrm{x}$ & & & & & & \\
\hline 3 & $\begin{array}{l}\text { Mehrabi, Ulsoy and Koren } \\
\text { (2000b) }\end{array}$ & $\mathrm{x}$ & $\mathrm{x}$ & $\mathrm{x}$ & $\mathrm{x}$ & & $\mathrm{x}$ & & & & & & \\
\hline 4 & $\begin{array}{l}\text { Landers, Min and Koren } \\
\text { (2001) }\end{array}$ & $\mathrm{x}$ & & & $\mathrm{x}$ & & $\mathrm{x}$ & & & & & & \\
\hline 5 & $\begin{array}{l}\text { Son, Olsen, and Yip-Hoi } \\
\text { (2001) }\end{array}$ & & & & & $\mathrm{x}$ & & & & & & & \\
\hline 6 & Kuo (2001) & $\mathrm{x}$ & $\mathrm{x}$ & $\mathrm{x}$ & $\mathrm{x}$ & & $\mathrm{x}$ & & & & & & \\
\hline 7 & Koren and Ulsoy (2002) & $x$ & $x$ & $x$ & $x$ & & $x$ & & & & & & \\
\hline 8 & Moon and Kota (2002) & $\mathrm{x}$ & & & $\mathrm{x}$ & & & & & & & & $\mathrm{x}$ \\
\hline 9 & Zhang et al. (2002) & & & & & $\mathrm{x}$ & & & & & & & \\
\hline 10 & Abdi and Labib (2003) & $\mathrm{x}$ & $\mathrm{x}$ & $\mathrm{x}$ & $\mathrm{x}$ & & $\mathrm{x}$ & & & & & & \\
\hline 11 & Yu et al. (2003) & & & & $x$ & $x$ & & & & & & & \\
\hline 12 & Abdi and Labib (2004a) & $\mathrm{x}$ & & & $x$ & $x$ & & & & & & & \\
\hline 13 & Liu et al. (2004) & & & $\mathrm{x}$ & & & & & & & & & \\
\hline 14 & Pérez et al. (2004) & $\mathrm{x}$ & $\mathrm{x}$ & $x$ & $\mathrm{x}$ & & $\mathrm{x}$ & & & & & & \\
\hline 15 & Setchi and Lagos (2004) & $\mathrm{x}$ & $x$ & $x$ & $x$ & & $x$ & & & & & & \\
\hline 16 & Tang and Qiu (2004) & $x$ & & & & & $x$ & & & & & & \\
\hline 17 & Koren (2005) & $x$ & $\mathrm{x}$ & $\mathrm{x}$ & $\mathrm{x}$ & $\mathrm{x}$ & $x$ & & & & & & \\
\hline 18 & Molina et al. (2005) & $\mathrm{x}$ & $\mathrm{x}$ & $\mathrm{x}$ & $\mathrm{x}$ & & $\mathrm{x}$ & & & & & & \\
\hline 19 & $\begin{array}{l}\text { Spicer, Yip-Hoi and Koren } \\
(2005)\end{array}$ & $x$ & $\mathrm{x}$ & $\mathrm{x}$ & $\mathrm{x}$ & $\mathrm{x}$ & $\mathrm{x}$ & & & & & & \\
\hline 20 & Elmaraghy (2006) & $\mathrm{x}$ & $\mathrm{x}$ & $\mathrm{x}$ & $\mathrm{x}$ & $\mathrm{x}$ & $\mathrm{x}$ & $\mathrm{x}$ & $\mathrm{x}$ & $\mathrm{x}$ & & & \\
\hline 21 & Farid and McFarlane (2006) & $x$ & $x$ & $\mathrm{x}$ & $x$ & & $\mathrm{x}$ & & & & & & \\
\hline 22 & Koren (2006) & $\mathrm{x}$ & $\mathrm{x}$ & $\mathrm{x}$ & $\mathrm{x}$ & $\mathrm{x}$ & $\mathrm{x}$ & & & & & & \\
\hline 23 & Zhang (2006) & $x$ & $x$ & & & & $x$ & & & & & & $\mathrm{x}$ \\
\hline 24 & $\begin{array}{l}\text { Ayman, Youssef and } \\
\text { EIMaraghy (2007) }\end{array}$ & & & & $\mathrm{x}$ & $\mathrm{x}$ & & & & & & & \\
\hline 25 & Azab and Elmaraghy (2007) & $x$ & $x$ & $x$ & $x$ & $x$ & $\mathrm{x}$ & & & & & & \\
\hline 26 & $\begin{array}{l}\text { Cao, Elmaraghy and Azab } \\
(2007)\end{array}$ & & & & $x$ & $x$ & & & & & & & \\
\hline 27 & Deif and Elmaraghy (2007a) & $x$ & $\mathrm{x}$ & $x$ & $x$ & $x$ & $x$ & & & & & & \\
\hline 28 & Deif and Elmaraghy (2007b) & $x$ & $x$ & $\mathrm{x}$ & $x$ & & $x$ & & & & & & \\
\hline 29 & Dhupia et al. (2007) & $x$ & $x$ & $x$ & $x$ & $x$ & $x$ & & & & & & \\
\hline 30 & Elmaraghy (2007) & & & & $\mathrm{x}$ & $x$ & & & & & & & \\
\hline 31 & Galan et al. (2007) & $x$ & & & & & & & & & & & \\
\hline 32 & Katz (2007) & $x$ & $\mathrm{x}$ & $\mathrm{x}$ & $\mathrm{x}$ & $\mathrm{x}$ & $\mathrm{x}$ & & & & & & \\
\hline 33 & $\begin{array}{l}\text { Singh, Khilwani and Tiwari } \\
(2007)\end{array}$ & $x$ & $x$ & $\mathrm{x}$ & $\mathrm{x}$ & $\mathrm{x}$ & $x$ & & & & & & \\
\hline 34 & Spicer and Carlo (2007) & & & & & $x$ & & & & & & & \\
\hline 35 & Wiendahl et al. (2007) & $\mathrm{x}$ & & & $\mathrm{x}$ & $\mathrm{x}$ & $\mathrm{x}$ & $\mathrm{x}$ & $\mathrm{x}$ & $\mathrm{x}$ & $\mathrm{x}$ & & \\
\hline 36 & $\begin{array}{l}\text { Yu, Zhang and Klemm } \\
(2007)\end{array}$ & & & & & & & & & & & $x$ & \\
\hline 37 & Bi et al. (2008a) & $\mathrm{x}$ & $\mathrm{x}$ & $\mathrm{x}$ & $\mathrm{x}$ & $\mathrm{x}$ & $\mathrm{x}$ & & & & & & \\
\hline 38 & Bi et al. (2008b) & $x$ & $x$ & $x$ & $x$ & $x$ & $x$ & & & & & & \\
\hline 39 & $\begin{array}{l}\text { Abbasi and Houshmand } \\
(2009)\end{array}$ & $\mathrm{x}$ & $\mathrm{x}$ & $\mathrm{x}$ & $\mathrm{x}$ & & $\mathrm{x}$ & & & & & & \\
\hline 40 & Abdi (2009) & $x$ & $x$ & $\mathrm{x}$ & $x$ & & $x$ & & & & & & \\
\hline 41 & EIMaraghy (2009) & & & & & & $x$ & & & & & & \\
\hline 42 & Kannan and Saha (2009) & $\mathrm{x}$ & $\mathrm{x}$ & & $\mathrm{x}$ & $\mathrm{x}$ & $x$ & & & & & & \\
\hline 43 & Koren and Shpitalni (2010) & $x$ & $x$ & $\mathrm{x}$ & $x$ & $x$ & $x$ & & & & & & \\
\hline 44 & Meng (2010) & $\mathrm{x}$ & $x$ & $x$ & $x$ & & $x$ & & & & & & \\
\hline 45 & Renna (2010) & $\mathrm{x}$ & $\mathrm{x}$ & $\mathrm{x}$ & $\mathrm{x}$ & $\mathrm{x}$ & $\mathrm{x}$ & & & & & & \\
\hline
\end{tabular}




\begin{tabular}{|c|c|c|c|c|c|c|c|c|c|c|c|c|c|}
\hline 46 & Zhang et al. (2010) & $\mathrm{X}$ & $x$ & $x$ & $x$ & & $x$ & & & & & & \\
\hline 47 & $\begin{array}{l}\text { Abbasi and Houshmand } \\
(2011)\end{array}$ & $\mathrm{x}$ & $\mathrm{x}$ & $\mathrm{x}$ & $x$ & & $\mathrm{x}$ & & & & & & \\
\hline 48 & $\mathrm{Bi}(2011)$ & $x$ & $x$ & $x$ & $\mathrm{X}$ & $\mathrm{X}$ & & & & & & & \\
\hline 49 & Gumasta et al. (2011) & $x$ & $x$ & $x$ & $x$ & $x$ & $x$ & & & & & & \\
\hline 50 & Ribeiro and Barata (2011) & $x$ & $x$ & $x$ & $x$ & $x$ & $x$ & & & & & & \\
\hline 51 & Rösiö (2011) & $x$ & $x$ & $x$ & $x$ & $x$ & $x$ & $x$ & & & $x$ & & \\
\hline 52 & $\begin{array}{l}\text { Chaube, Benyoucef and } \\
\text { Tiwari (2012) }\end{array}$ & $\mathrm{x}$ & $\mathrm{x}$ & $\mathrm{x}$ & $x$ & & & & & & & & \\
\hline 53 & Goyal, Jain and Jain (2012) & $x$ & & $x$ & $x$ & $x$ & & & & & & & \\
\hline 54 & $\begin{array}{l}\text { Leitão, Barbosa and } \\
\text { Trentesauxc (2012) }\end{array}$ & & & & & & & & & & & $\mathrm{x}$ & \\
\hline 55 & $\begin{array}{l}\text { Niroomand, Kuzgunkaya and } \\
\text { Bulgak (2012) }\end{array}$ & $\mathrm{X}$ & & & & $x$ & & & & & & & \\
\hline 56 & Rösiö (2012) & $x$ & $x$ & $x$ & $x$ & $\mathrm{X}$ & & $x$ & & & $x$ & & \\
\hline 57 & Saxena and Jain (2012) & $x$ & $x$ & $x$ & $x$ & $x$ & $x$ & & & & & & \\
\hline 58 & Wang and Koren (2012) & & & & & $x$ & & & & & & & \\
\hline 59 & $\begin{array}{l}\text { Aguilar, Roman-Flores and } \\
\text { Huegel (2013) }\end{array}$ & $X$ & $X$ & $X$ & $X$ & $X$ & $X$ & & & & & & \\
\hline 60 & $\begin{array}{l}\text { Bensmaine, Dahane, and } \\
\text { Benyoucef (2013) }\end{array}$ & & & & & & $x$ & & & & & & \\
\hline 61 & $\begin{array}{l}\text { Essafi, Delorme and Dolgui } \\
\text { (2013) }\end{array}$ & $\mathrm{X}$ & $\mathrm{X}$ & $\mathrm{X}$ & $x$ & & $\mathrm{x}$ & & & & & & \\
\hline 62 & Koren (2013) & $x$ & $x$ & $x$ & $x$ & $x$ & $x$ & & & & & & \\
\hline 63 & Rösiö and Säfsten (2013) & $x$ & $x$ & $x$ & $x$ & $x$ & $x$ & $X$ & & & $x$ & & \\
\hline 64 & $\begin{array}{l}\text { Silva Belisario and Pierreval } \\
(2013)\end{array}$ & $x$ & & & & & & & & $x$ & & $\mathrm{X}$ & \\
\hline 65 & Yan and Vyatkin (2013) & $x$ & & & & & $x$ & & & & & & $\mathrm{x}$ \\
\hline 66 & Farid (2014) & $x$ & $x$ & $x$ & $x$ & & $x$ & & & & & & \\
\hline 67 & Koren (2014) & $x$ & $x$ & $x$ & $x$ & $x$ & $x$ & & & & & & \\
\hline 68 & $\begin{array}{l}\text { Makinde, Mpofu and } \\
\text { Popoola (2014) }\end{array}$ & $x$ & $x$ & $x$ & $x$ & $\mathrm{X}$ & $\mathrm{X}$ & & & & & & \\
\hline 69 & Mesa et al. (2014) & $x$ & $x$ & $x$ & $x$ & $x$ & $x$ & $x$ & $x$ & $x$ & & & $\mathrm{x}$ \\
\hline 70 & $\begin{array}{l}\text { Nejad, Niroomand and } \\
\text { Kuzgunkaya (2014) }\end{array}$ & $x$ & & & & $x$ & & & & & & & \\
\hline 71 & $\begin{array}{l}\text { Niroomand, Kuzgunkaya and } \\
\text { Bulgak (2014) }\end{array}$ & $x$ & & & & $x$ & & & & & & & \\
\hline 72 & $\begin{array}{l}\text { Dubei, Gunasekaran and } \\
\text { Chakrabarty (2015) }\end{array}$ & $x$ & $\mathrm{X}$ & $x$ & $x$ & $\mathrm{X}$ & $x$ & & & & & & \\
\hline 73 & Hees and Reinhart (2015) & $x$ & $x$ & $x$ & $x$ & $x$ & $x$ & & & & & & \\
\hline 74 & Unglert et al. (2015) & $x$ & $x$ & & $x$ & & $x$ & & & & & & \\
\hline 75 & $\begin{array}{l}\text { Wu, Wang and Schaefer } \\
(2015)\end{array}$ & $\mathrm{X}$ & $x$ & $x$ & $x$ & & $\mathrm{x}$ & & & & & & \\
\hline 76 & Carpanzano et al. (2016) & $x$ & $x$ & & & & & & & & & & \\
\hline 77 & Koren, Wang and Gu (2016) & $x$ & $x$ & $x$ & $x$ & $\mathrm{X}$ & $x$ & & & & & & \\
\hline 78 & Kruger and Basson (2016) & $x$ & $x$ & $x$ & $x$ & $\mathrm{x}$ & $x$ & & & & & & \\
\hline 79 & Scholz et al. (2016) & $x$ & & & & $x$ & & & & & & & $\mathrm{x}$ \\
\hline 80 & Vafadar et al. (2016) & $x$ & & & & $x$ & & & & & & & $\mathrm{x}$ \\
\hline 81 & Abdi and Labib (2017) & $x$ & $x$ & $x$ & $x$ & $\mathrm{x}$ & $x$ & & & & & & \\
\hline 82 & Dubei et al. (2017) & $\mathrm{X}$ & $x$ & $x$ & $x$ & $x$ & $x$ & & & & & & \\
\hline 83 & $\begin{array}{l}\text { Haddou Benderbal, Dahane } \\
\text { and Benyoucef (2017) }\end{array}$ & $x$ & $x$ & $x$ & $x$ & $x$ & $x$ & & & & & & \\
\hline 84 & Prasad and Jayswal (2017) & $\mathrm{X}$ & $x$ & $x$ & $x$ & $x$ & $x$ & & & & & & \\
\hline 85 & $\begin{array}{l}\text { Pugliese, Mesa and Maury } \\
\text { (2017) }\end{array}$ & $x$ & $x$ & $x$ & $x$ & $x$ & $x$ & & & & & & \\
\hline 86 & Weng, He, and Pan (2017) & $x$ & $x$ & $x$ & $x$ & $x$ & $x$ & & & & & & \\
\hline & & 73 & 59 & 57 & 66 & 52 & 61 & 6 & 3 & 4 & 4 & 3 & 6 \\
\hline
\end{tabular}


Table 2 Reconfigurability characteristics and reconfiguration effort

\begin{tabular}{|c|c|c|c|}
\hline & \multicolumn{3}{|c|}{ Reconfiguration effort } \\
\hline & Ramp-up Time & Reconfiguration Time & Reconfiguration Cost \\
\hline $\begin{array}{l}\frac{7}{\frac{7}{2}} \\
\frac{10}{3} \\
\frac{0}{0} \\
\sum\end{array}$ & & $\begin{array}{l}\text { Koren et al. (1999) } \\
\text { Koren (2013) } \\
\text { Puik et al. (2016) } \\
\text { Elmaraghy (2006) } \\
\text { Rösiö (2012) }\end{array}$ & $\begin{array}{l}\text { Puik et al. (2016) } \\
\text { Heisel and Meitzner (2006) } \\
\text { Mesa et al. (2014) } \\
\text { Elmaraghy (2006) } \\
\text { Katz (2007) }\end{array}$ \\
\hline 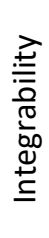 & & $\begin{array}{l}\text { Koren et al. (1999) } \\
\text { Koren (2013) } \\
\text { Aboufazeli (2011) } \\
\text { Elmaraghy (2006) } \\
\text { Weng, He and Pan (2017) } \\
\text { Rösiö (2012) }\end{array}$ & $\begin{array}{l}\text { Koren (2013) } \\
\text { Heisel and Meitzner (2006) } \\
\text { Elmaraghy (2006) } \\
\text { Weng, He and Pan (2017) }\end{array}$ \\
\hline 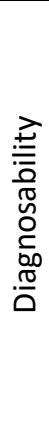 & $\begin{array}{l}\text { Koren et al. (1999) } \\
\text { Koren (2013) } \\
\text { Koren and Shpitalni (2010) } \\
\text { Bi et al. (2008) } \\
\text { Mehrabi and Kannatey-Asibu } \\
\text { (2001) } \\
\text { Stoian and Frumusanu (2007) } \\
\text { Liu et al. (2004) } \\
\text { Koren (2005) } \\
\text { Weng, He and Pan (2017) } \\
\text { Rösiö (2012) }\end{array}$ & $\begin{array}{l}\text { Elmaraghy (2006) } \\
\text { Koren et al. (1999) }\end{array}$ & Elmaraghy (2006) \\
\hline 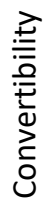 & & $\begin{array}{l}\text { Ayman, Youssef and EIMaraghy } \\
\text { (2006) } \\
\text { Elmaraghy (2006) }\end{array}$ & $\begin{array}{l}\text { Ayman, Youssef and EIMaraghy } \\
\text { (2006) } \\
\text { Landers, Min and Koren (2001) } \\
\text { Elmaraghy (2006) } \\
\text { Koren et al. (1999) }\end{array}$ \\
\hline 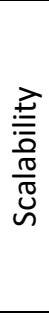 & & $\begin{array}{l}\text { Ayman, Youssef and EIMaraghy } \\
\text { (2006) } \\
\text { Scholz-Reiter, Lappe, and } \\
\text { Grundstein (2015) } \\
\text { Niroomand, Kuzgunkaya, and } \\
\text { Bulgak (2014) } \\
\text { Koren, Wang and Gu (2016) } \\
\text { Elmaraghy (2006) }\end{array}$ & $\begin{array}{l}\text { Ayman, Youssef and EIMaraghy } \\
\text { (2006) } \\
\text { Koren, Wang and Gu (2016) } \\
\text { Elmaraghy (2006) } \\
\text { Koren et al. (1999) }\end{array}$ \\
\hline 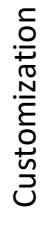 & & & $\begin{array}{l}\text { Koren (2013) } \\
\text { Landers, Min and Koren (2001) } \\
\text { Chaube, Benyoucef and Tiwari } \\
\text { (2012) }\end{array}$ \\
\hline
\end{tabular}


Table 3 Classification of characteristics in configuration and reconfiguration ones

\begin{tabular}{|c|c|c|c|c|c|c|}
\hline \multirow[b]{2}{*}{ Authors } & \multicolumn{3}{|c|}{ 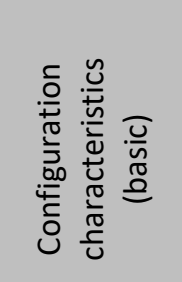 } & \multicolumn{3}{|c|}{ 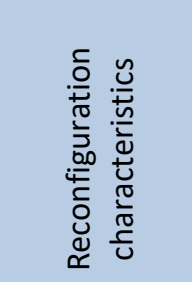 } \\
\hline & 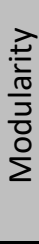 & 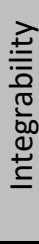 & \multicolumn{2}{|c|}{ 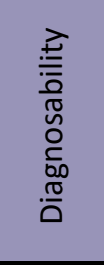 } & 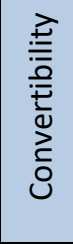 & 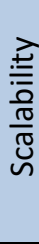 \\
\hline Koren (2005) & $\mathrm{x}$ & $\mathrm{x}$ & $\mathrm{X}$ & & $\mathrm{x}$ & $\mathrm{x}$ \\
\hline Wiendahl et al. (2007) & $\mathrm{x}$ & $\mathrm{x}$ & $X$ & & $x$ & $x$ \\
\hline Koren and Shpitalni (2010) & $\mathrm{x}$ & $\mathrm{x}$ & $\mathrm{X}$ & & & \\
\hline Rösiö (2012) & $\mathrm{x}$ & $\mathrm{X}$ & $x$ & & $\mathrm{x}$ & $\mathrm{x}$ \\
\hline Hasan, Jain and Kumar (2014) & $\mathrm{x}$ & $\mathrm{X}$ & $X$ & & $\mathrm{x}$ & $\mathrm{x}$ \\
\hline Mehrabi and Kannatey-Asibu (2001) & & & & $\mathrm{x}$ & & \\
\hline Koren and Ulsoy (2002) & & & & & & $\mathrm{x}$ \\
\hline Koren and Katz (2003) & & & & $x$ & & \\
\hline Liu et al. (2004) & & & & $x$ & & \\
\hline Tang and Qiu (2004) & $\mathrm{x}$ & & & & $\mathrm{x}$ & $\mathrm{x}$ \\
\hline Heisel and Meitzner (2006) & $x$ & $\mathrm{X}$ & & & $x$ & $\mathrm{x}$ \\
\hline Abbasi and Houshmand (2011) & & & & & $\mathrm{x}$ & $\mathrm{x}$ \\
\hline Valente (2016) & $\mathrm{X}$ & $\mathrm{X}$ & & $\mathrm{x}$ & $\mathrm{x}$ & \\
\hline Son, Olsen, and Yip-Hoi (2001) & & & & & & $x$ \\
\hline Bruccoleri, Amico and Perrone (2003) & & & & $x$ & & \\
\hline Bruccoleri, Pasek and Koren (2006) & & & & $x$ & $\mathrm{x}$ & \\
\hline Deif and EIMaraghy (2006) & & & & & & $x$ \\
\hline Deif and Elmaraghy (2007a) & $\mathrm{X}$ & $\mathrm{X}$ & & & & $\mathrm{x}$ \\
\hline Deif and Elmaraghy (2007b) & $x$ & & & & $\mathrm{x}$ & $\mathrm{X}$ \\
\hline Galan et al. (2007) & & & & & $x$ & $x$ \\
\hline Elmaraghy (2009) & $\mathrm{x}$ & & & & $\mathrm{x}$ & $\mathrm{x}$ \\
\hline Chaube, Benyoucef and Tiwari (2012) & $\mathrm{X}$ & & & & $\mathrm{x}$ & $\mathrm{X}$ \\
\hline Goyal, Jain and Jain (2012) & $\mathrm{x}$ & & & & $x$ & $\mathrm{x}$ \\
\hline Azevedo, Crispim and Sousa (2017) & & & & & & $\mathrm{x}$ \\
\hline Freiheit et al. (2004) & & & $\underline{x}$ & $\mathrm{x}$ & & \\
\hline Muller, Grunewald and Spengler (2017) & & & $x$ & $x$ & & \\
\hline
\end{tabular}


Table 4 Relationships between reconfigurability characteristics

\begin{tabular}{|c|c|c|c|c|c|c|c|}
\hline & & \multicolumn{6}{|c|}{ INFLUENCED CHARACTERISTICS } \\
\hline & & Integrability & Modularity & Diagnosability & Scalability & Convertibility & Customization \\
\hline \multirow{5}{*}{ 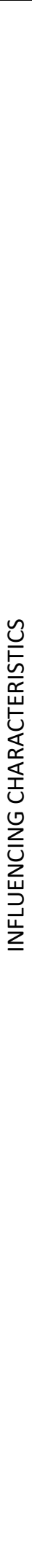 } & 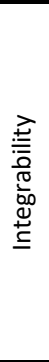 & & $\begin{array}{l}\text { Mehrabi et al. } \\
\text { 2000a; } \\
\text { Kusiak 2002; } \\
\text { Shaik, Rao and } \\
\text { Rao 2014; } \\
\text { Puik et al. 2016; } \\
\text { Bi et al. 2008a; } \\
\text { Mesa et al. 2014; } \\
\text { Weng, He and } \\
\text { Pan 2017; } \\
\text { Prasad and } \\
\text { Jayswal } 2017\end{array}$ & $\begin{array}{l}\text { Garetti et al. } \\
\text { 2015; } \\
\text { Negri et al. 2016; } \\
\text { Valente 2016; } \\
\text { Bruccoleri, Amico } \\
\text { and Perrone } 2003\end{array}$ & $\begin{array}{l}\text { Heisel and } \\
\text { Meitzner 2006; } \\
\text { Koren 2006; } \\
\text { Wiendahl et al. } \\
\text { 2007; } \\
\text { Rösiö 2012; } \\
\text { Deif and } \\
\text { Elmaraghy 2007a }\end{array}$ & $\begin{array}{l}\text { Heisel and } \\
\text { Meitzner 2006; } \\
\text { Koren 2006; } \\
\text { Wiendahl et al. } \\
\text { 2007; } \\
\text { Valente 2016; } \\
\text { Rösiö } 2012\end{array}$ & $\begin{array}{l}\text { Mehrabi et al. } \\
\text { 2000a; } \\
\text { Koren 2006; } \\
\text { Wiendahl et al. } \\
\text { 2007; } \\
\text { Elmaraghy 2006; } \\
\text { Meng } 2010\end{array}$ \\
\hline & $\begin{array}{l}\frac{7}{\frac{7}{2}} \\
\frac{\pi}{5} \\
\frac{7}{0} \\
\frac{0}{2}\end{array}$ & $\begin{array}{l}\text { Mehrabi et al. } \\
\text { 2000a; } \\
\text { Kusiak 2002; } \\
\text { Shaik et al. 2014; } \\
\text { Puik et al. 2016; } \\
\text { Bi et al. 2008a; } \\
\text { Mesa et al. 2014; } \\
\text { Weng, He and } \\
\text { Pan 2017; } \\
\text { Prasad and } \\
\text { Jayswal } 2017\end{array}$ & & $\begin{array}{l}\text { Garetti et al. } \\
\text { 2015; } \\
\text { Negri et al. 2016; } \\
\text { Valente 2016; } \\
\text { Bruccoleri, Amico } \\
\text { and Perrone } \\
\text { 2003; } \\
\text { Bruccoleri, Pasek } \\
\text { and Koren } 2006\end{array}$ & $\begin{array}{l}\text { Heisel and } \\
\text { Meitzner 2006; } \\
\text { Koren 2006; } \\
\text { Wiendahl et al. } \\
\text { 2007; } \\
\text { Koren and } \\
\text { Shpitalni 2010; } \\
\text { Deif and } \\
\text { ElMaraghy 2007a; } \\
\text { Wang and Koren } \\
\text { 2012; } \\
\text { Mehrabi et al. } \\
\text { 2000b; } \\
\text { Chaube et al. } \\
\text { 2012; } \\
\text { Goyal, Jain and } \\
\text { Jain 2012; } \\
\text { Elmaraghy 2009; } \\
\text { Spicer, Yip-Hoi } \\
\text { and Koren 2005; } \\
\text { Scholz et al. 2016; } \\
\text { Rösiö 2012; } \\
\text { Deif and } \\
\text { Elmaraghy 2007b }\end{array}$ & $\begin{array}{l}\text { Heisel and } \\
\text { Meitzner 2006; } \\
\text { Koren 2006; } \\
\text { Wiendahl et al. } \\
2007 ; \\
\text { Koren and } \\
\text { Shpitalni 2010; } \\
\text { Gumasta et al. } \\
2011 ; \\
\text { Mehrabi et al. } \\
\text { 2000b; } \\
\text { Valente 2016; } \\
\text { Chaube et al. } \\
\text { 2012; } \\
\text { Goyal, Jain and } \\
\text { Jain 2012; } \\
\text { Elmaraghy 2009; } \\
\text { Rösiö 2012 }\end{array}$ & $\begin{array}{l}\text { Mehrabi et al. } \\
\text { 2000a; } \\
\text { Koren 2006; } \\
\text { Shaik, Rao and } \\
\text { Rao 2014; } \\
\text { Wiendahl et al. } \\
\text { 2007; } \\
\text { Puik et al. 2016; } \\
\text { Fredriksson 2006; } \\
\text { Zhang et al. 2015; } \\
\text { Elmaraghy 2009; } \\
\text { Elmaraghy 2006; } \\
\text { Tang and Qiu } \\
\text { 2004; } \\
\text { Meng 2010; } \\
\text { Abdi and Labib } \\
\text { 2004b }\end{array}$ \\
\hline & 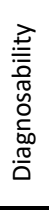 & - & - & & $\begin{array}{l}\text { Koren 2013; } \\
\text { Zhang et al. 2006; } \\
\text { Wiendahl et al. } \\
\text { 2007; } \\
\text { Kruger and } \\
\text { Basson 2016; } \\
\text { Rösiö } 2012 \\
\end{array}$ & $\begin{array}{l}\text { Zhang et al. 2006; } \\
\text { Wiendahl et al. } \\
\text { 2007; } \\
\text { Bruccoleri, Pasek } \\
\text { and Koren 2006; } \\
\text { Rösiö } 2012\end{array}$ & $\begin{array}{l}\text { Koren 2006; } \\
\text { Wiendahl et al. } \\
\text { 2007; } \\
\text { Elmaraghy } 2006\end{array}$ \\
\hline & 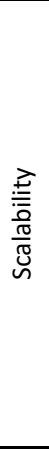 & - & - & - & & - & $\begin{array}{l}\text { Heisel and } \\
\text { Meitzner 2006; } \\
\text { Shabaka and } \\
\text { ElMaraghy 2007; } \\
\text { Elmaraghy 2009; } \\
\text { Koren et al. 2016; } \\
\text { Elmaraghy 2006; } \\
\text { Galan et al. 2007; } \\
\text { Abbasi and } \\
\text { Houshmand } \\
2011 \text {; } \\
\text { Hees and } \\
\text { Reinhart 2015; } \\
\text { Koren and Ulsoy } \\
2002\end{array}$ \\
\hline & 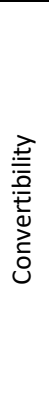 & - & - & - & - & & $\begin{array}{l}\text { Heisel and } \\
\text { Meitzner 2006; } \\
\text { Shabaka and } \\
\text { ElMaraghy 2007; } \\
\text { Landers, Min and } \\
\text { Koren 2001; } \\
\text { Elmaraghy 2009; } \\
\text { Elmaraghy 2006; } \\
\text { Galan et al. 2007; } \\
\text { Abbasi and } \\
\text { Houshmand } \\
\text { 2011; } \\
\text { Hees and } \\
\text { Reinhart } 2015\end{array}$ \\
\hline
\end{tabular}




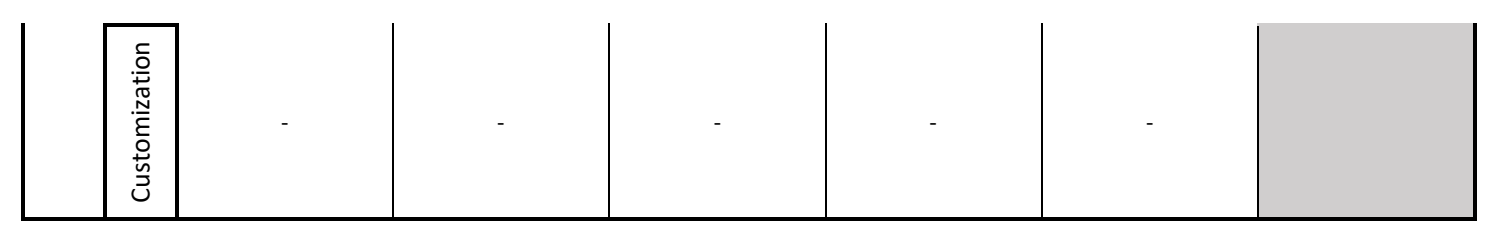


Table 5 Relationships of reconfigurability characteristics with production levels (references are summarised through identification numbers introduced in Table 1)

\begin{tabular}{|c|c|c|c|}
\hline & Workstation level & System level & Factory level \\
\hline Modularity & $\begin{array}{l}4,8,18,19,22,23,31,37,38, \\
42,48,53,55,59,64,69,70,80, \\
85\end{array}$ & $\begin{array}{l}1,2,3,6,7,10,12,14,15,16,17, \\
18,19,20,21,22,25,27,28,29, \\
32,33,35,37,38,39,40,43,44, \\
45,46,47,48,49,50,51,52,53, \\
56,57,59,61,62,63,65,66,67, \\
68,69,71,72,73,74,75,76,77, \\
78,79,81,83,82,84,85,86\end{array}$ & $20,22,35,37,38,48,69$ \\
\hline Integrability & $22,23,37,38,42,48,64,69,85$ & $\begin{array}{l}1,2,3,6,7,10,14,15,17,18,19, \\
20,21,22,25,27,28,29,32,33, \\
37,38,39,40,43,44,45,46,47, \\
48,49,50,51,52,56,57,59,61, \\
62,63,66,67,68,69,72,73,74, \\
75,76,77,78,81,82,83,84,85, \\
86\end{array}$ & $22,37,38,48,69$ \\
\hline Diagnosability & $22,37,38,48,69$ & $\begin{array}{l}1,2,3,6,7,10,13,14,15,17,18, \\
19,20,21,22,25,27,28,29,32, \\
33,37,38,39,40,43,44,45,46, \\
47,48,49,50,51,52,53,56,57, \\
59,61,62,63,66,67,68,69,72, \\
73,75,77,78,81,82,83,84,85, \\
86\end{array}$ & $22,37,38,48,69$ \\
\hline Convertibility & $\begin{array}{l}4,8,22,23,32,37,38,42,48, \\
59,69,85\end{array}$ & $\begin{array}{l}1,2,3,6,7,10,11,12,14,15,17, \\
18,19,20,21,22,24,25,26,27, \\
28,29,30,32,33,35,37,38,39, \\
40,43,44,45,46,47,48,49,50, \\
51,52,53,56,57,59,61,62,63, \\
66,67,68,69,72,73,74,75,77, \\
78,81,82,83,84,85,86\end{array}$ & $22,25,37,38,48,69,73,81$ \\
\hline Scalability & $19,22,32,42,48,59,69,85$ & $\begin{array}{l}5,9,11,12,17,19,20,22,24, \\
25,26,29,30,32,33,34,35,37, \\
38,43,45,48,49,50,51,53,55, \\
56,57,58,62,63,67,68,69,70, \\
71,72,77,78,79,82,83,84,85, \\
86\end{array}$ & $\begin{array}{l}20,22,25,27,35,37,38,48,55, \\
69,70,71,73,81\end{array}$ \\
\hline Customization & $\begin{array}{l}4,22,23,29,32,37,38,59,60 \\
69,80\end{array}$ & $\begin{array}{l}1,2,3,4,6,7,10,14,15,16,17, \\
18,19,20,21,22,25,27,28,29, \\
32,33,35,37,38,39,40,41,42, \\
43,44,45,46,47,49,50,51,57, \\
59,61,62,63,65,66,67,68,69, \\
72,73,74,75,77,78,81,82,83, \\
84,85,86\end{array}$ & $10,22,25,37,38,41,69,81$ \\
\hline
\end{tabular}


Table 6 Relationships between reconfigurability characteristics across levels

\begin{tabular}{|c|c|c|c|c|c|c|c|c|c|c|c|c|c|c|c|c|c|c|}
\hline & \multicolumn{6}{|c|}{ Workstation level } & \multicolumn{6}{|c|}{ System level } & \multicolumn{6}{|c|}{ Factory level } \\
\hline & 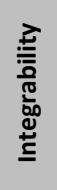 & $\begin{array}{l}\frac{Z}{\frac{Z}{2}} \\
\frac{\pi}{2} \\
\frac{7}{0} \\
\sum\end{array}$ & 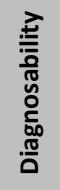 & 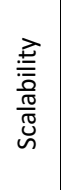 & 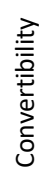 & 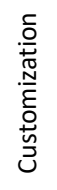 & 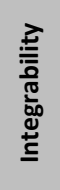 & $\begin{array}{l}\frac{2}{2} \\
\frac{10}{5} \\
\frac{0}{2} \\
\frac{0}{2}\end{array}$ & 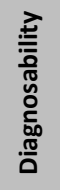 & 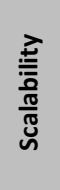 & 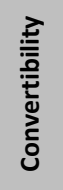 & 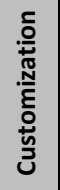 & 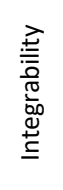 & $\begin{array}{l}\frac{\overrightarrow{2}}{\frac{1}{1}} \\
\frac{0}{5} \\
\frac{0}{0} \\
\frac{0}{2}\end{array}$ & 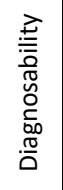 & 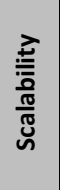 & 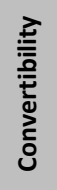 & 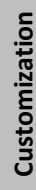 \\
\hline \begin{tabular}{|l|} 
Bruccoleri, \\
Amico and \\
Perrone 2003
\end{tabular} & $x$ & $x$ & $x$ & & & & & & $x$ & $x$ & & & & & & & & \\
\hline $\begin{array}{l}\text { Kannan and } \\
\text { Saha } 2009\end{array}$ & $x$ & $x$ & & $x$ & $x$ & & & & & & & $x$ & & & & & & \\
\hline $\begin{array}{l}\text { Bruccoleri, } \\
\text { Pasek and } \\
\text { Koren } 2006\end{array}$ & & $x$ & $x$ & & & & & & & & $x$ & & & & & & & \\
\hline $\begin{array}{l}\text { Landers, Min } \\
\text { and Koren } \\
2001\end{array}$ & & $x$ & & & $x$ & $x$ & & & & & & $x$ & & & & & & \\
\hline $\begin{array}{l}\text { Spicer, Yip- } \\
\text { Hoi and } \\
\text { Koren } 2005\end{array}$ & & $x$ & & $x$ & & & & & & $x$ & & & & & & & & \\
\hline $\begin{array}{l}\text { Vafadar, } \\
\text { Hayward and } \\
\text { Tolouei-Rad } \\
2017 \\
\end{array}$ & & $x$ & & & & & & & & & & $x$ & & & & & & \\
\hline $\begin{array}{l}\text { Bi et al. } \\
\text { 2008a }\end{array}$ & & & $x$ & & & & & & $x$ & & & & & & & & & \\
\hline $\begin{array}{l}\text { Kruger and } \\
\text { Basson } 2016\end{array}$ & & & $x$ & & & & & & $x$ & $x$ & & & & & & & & \\
\hline $\begin{array}{l}\text { Nejad, } \\
\text { Niroomand } \\
\text { and } \\
\text { Kuzgunkaya } \\
2014\end{array}$ & & $x$ & & & & & & & & $x$ & & & & & & $x$ & & \\
\hline $\begin{array}{l}\text { Niroomand, } \\
\text { Kuzgunkaya } \\
\text { and Bulgak } \\
2012\end{array}$ & & $\mathrm{x}$ & & & & & & & & $\mathrm{x}$ & & & & & & $x$ & & \\
\hline $\begin{array}{l}\text { Azab and } \\
\text { Elmaraghy } \\
2007\end{array}$ & & & & & & & $x$ & $x$ & $x$ & & $x$ & $x$ & & & & $x$ & $x$ & $x$ \\
\hline $\begin{array}{l}\text { Abdi and } \\
\text { Labib } 2017\end{array}$ & & & & & & & $x$ & $x$ & $x$ & & $x$ & $x$ & & & & $x$ & $x$ & $x$ \\
\hline \begin{tabular}{l|} 
Hees and \\
Reinhart 2015
\end{tabular} & & & & & & & $x$ & $x$ & $x$ & & $x$ & $x$ & & & & $x$ & $x$ & \\
\hline \begin{tabular}{l|} 
Abdi and \\
Labib 2003
\end{tabular} & & & & & & & $x$ & $x$ & $x$ & & $x$ & $x$ & & & & & & $x$ \\
\hline $\begin{array}{l}\text { Deif and } \\
\text { Elmaraghy } \\
\text { 2007a }\end{array}$ & & & & & & & $x$ & $x$ & $x$ & & $x$ & $x$ & & & & $x$ & & \\
\hline $\begin{array}{l}\text { Chaube, } \\
\text { Benyoucef } \\
\text { and Tiwari } \\
2012\end{array}$ & & & & & & & & $x$ & & & & & & & & $x$ & $x$ & $x$ \\
\hline $\begin{array}{l}\text { Niroomand, } \\
\text { Kuzgunkaya } \\
\text { and Bulgak } \\
2014\end{array}$ & & & & & & & & $x$ & & $x$ & & & & & & $x$ & & \\
\hline $\begin{array}{l}\text { Koren, Wang } \\
\text { and Gu } 2016\end{array}$ & & & & & & & & & & $x$ & & & & & & $x$ & & $x$ \\
\hline
\end{tabular}

